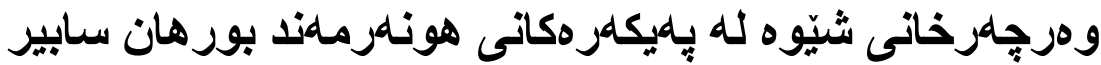

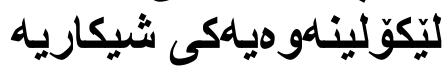

\section{Transformations of form in the sculptures of the artist Burhan Saber}

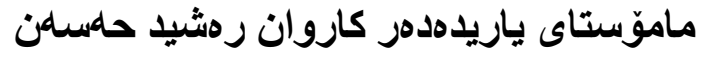

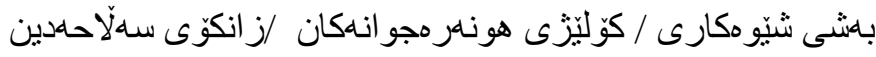 \\ karwan.hassan@su.edu.krd
}

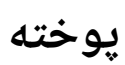

زانيارى تويَزينهوهكه

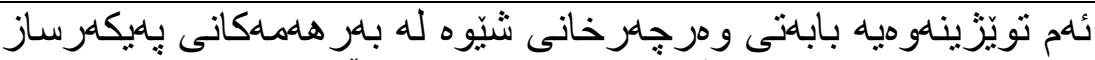

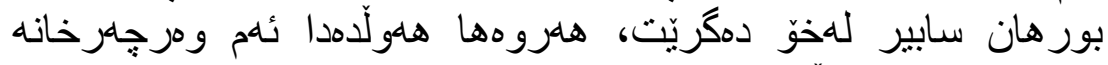

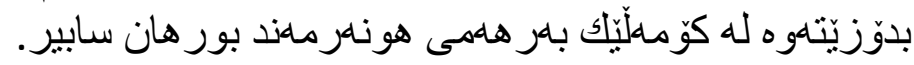

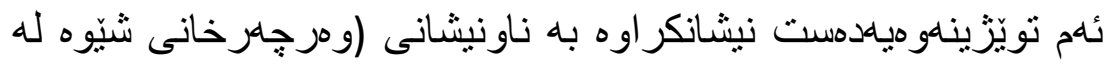

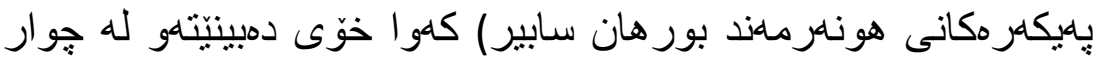

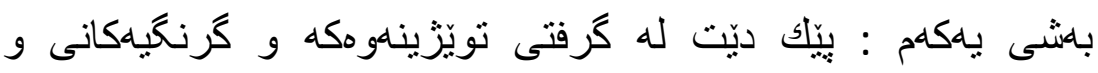

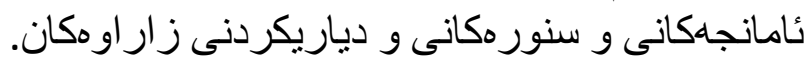

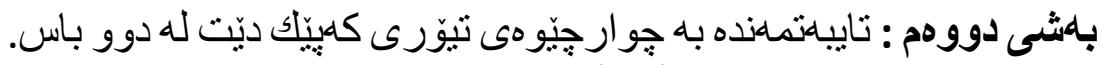

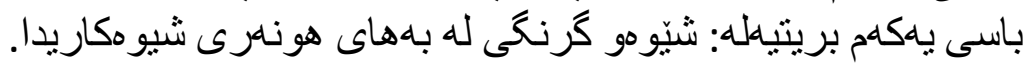

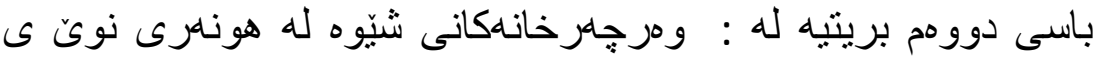

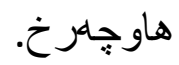

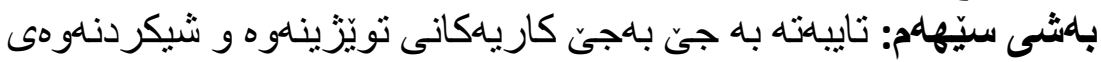

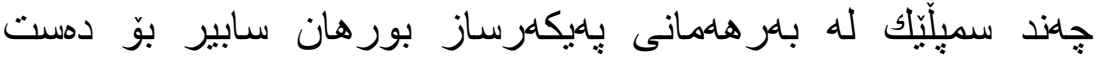

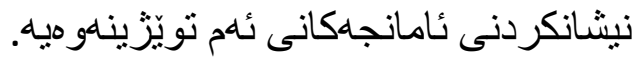

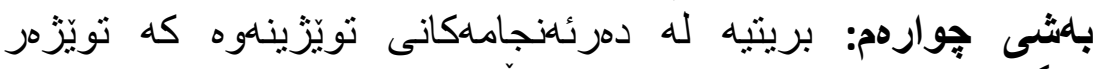

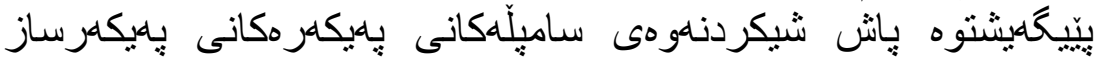

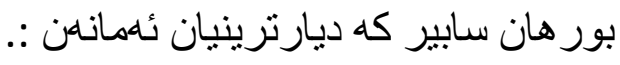

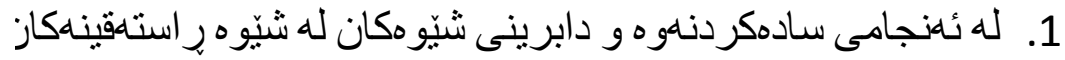

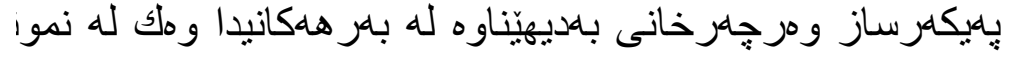

$$
\text { شيكر او مكاندا دياره. }
$$

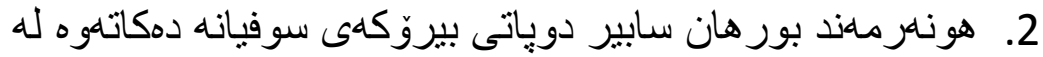

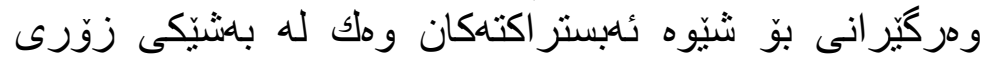




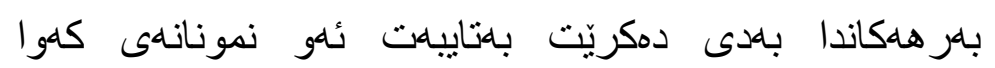

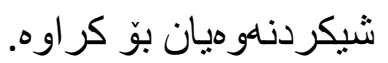

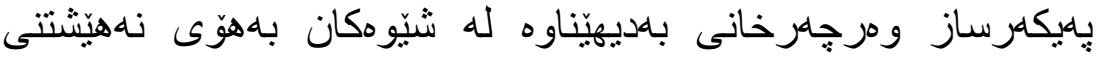

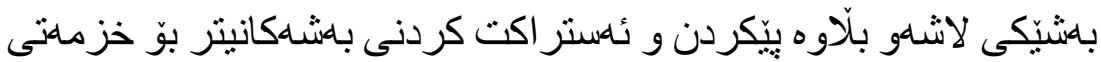

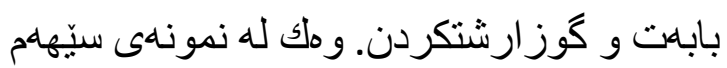

هونهر وهك سيّكته ريّكى كرنكى ناو سيّكته رهكانى شارستانيت هاوسهنگ يِيَشه كى:

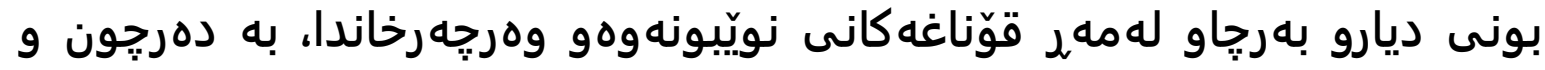

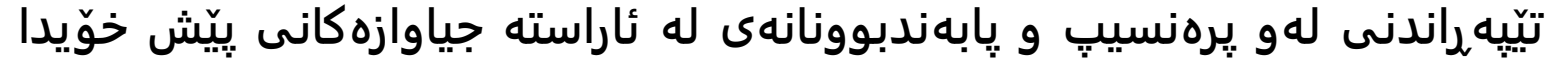

بونيان ههبورهان

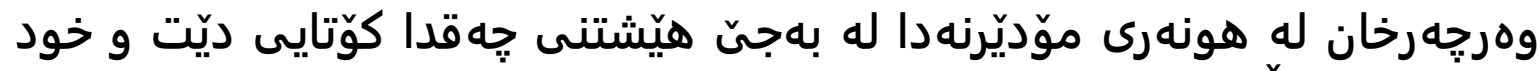

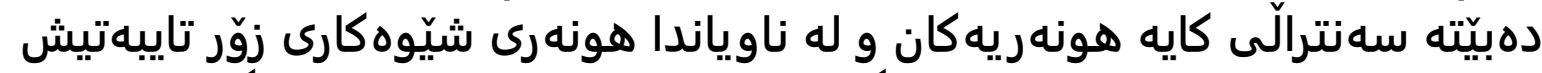
يهيكه رسازى دا كه له يه كهم ههنكاونها

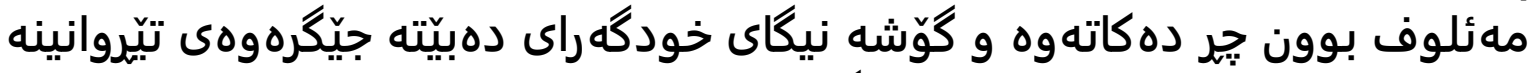

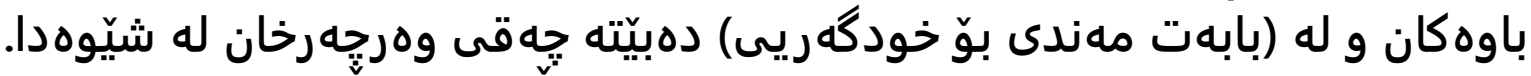

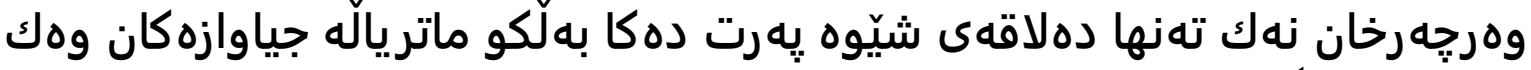

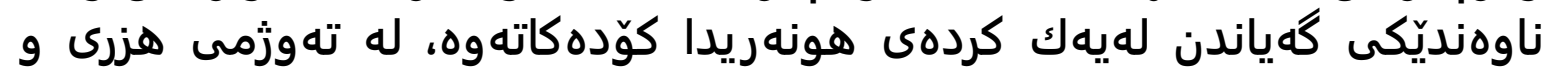
فهلسهفى جياوازدا دهيانكاته ئه زمونئن

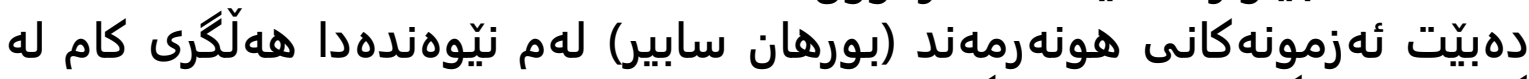

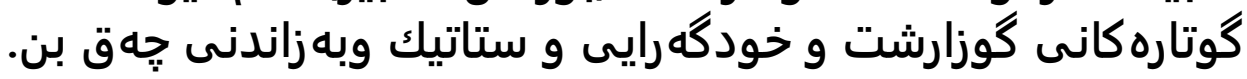

\section{به شى يه كهم : جِوارجِيِوهى كشتى تويّزَينهوه}

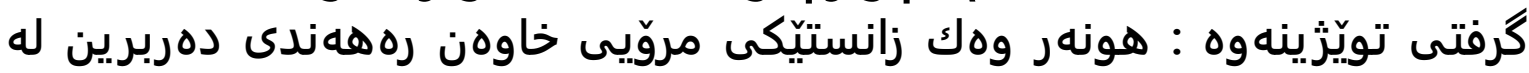

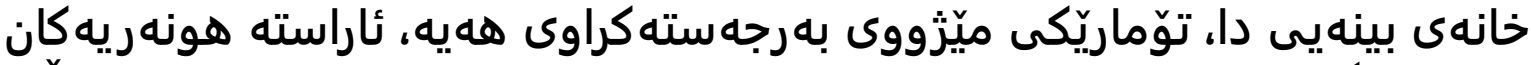

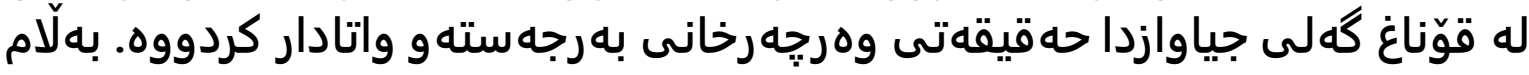

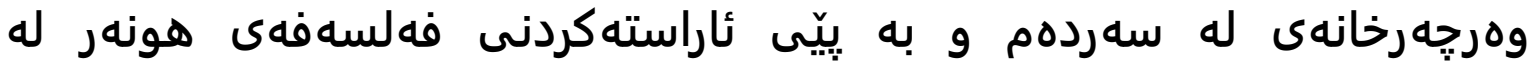

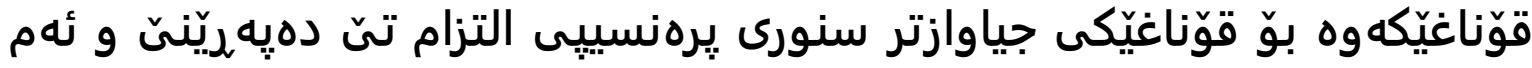




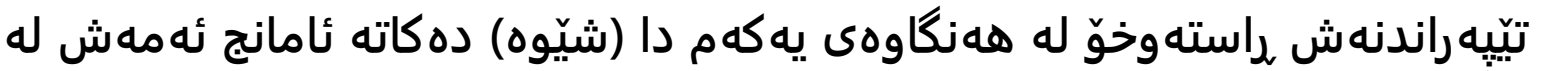

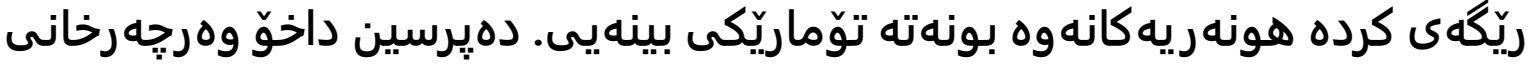

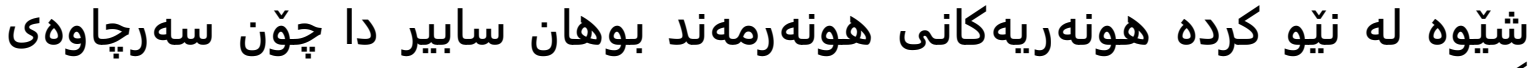

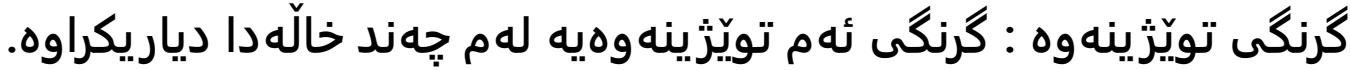

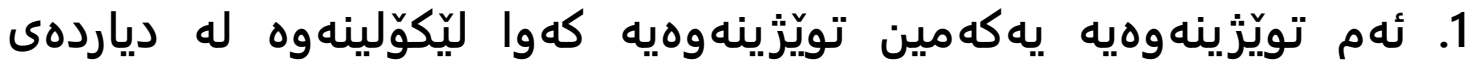

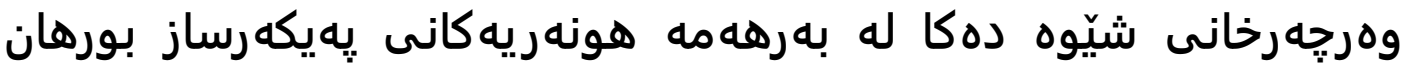
2. ئهم تويّزينهوهيه باسيّكه لهو ديارده داهيّنانه فراوان وبهربلًاوهى

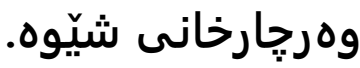

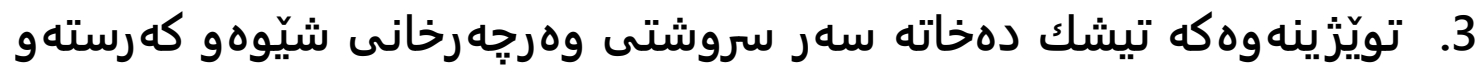

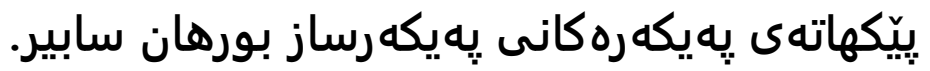

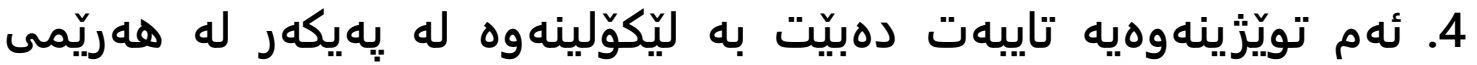

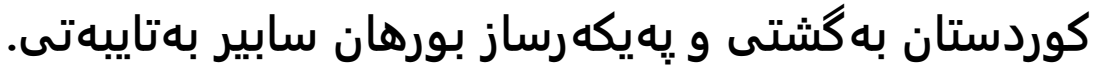

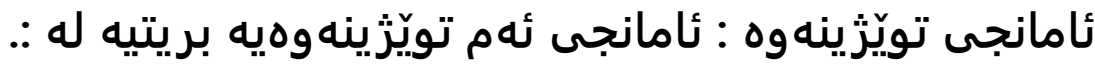

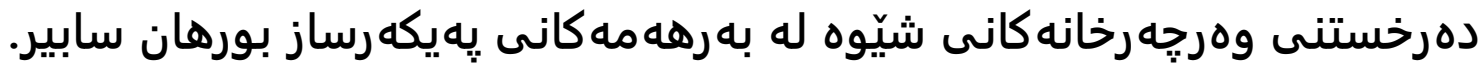

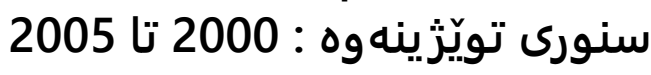

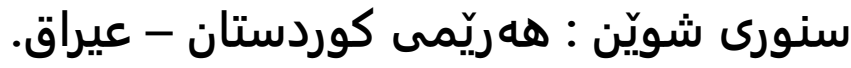

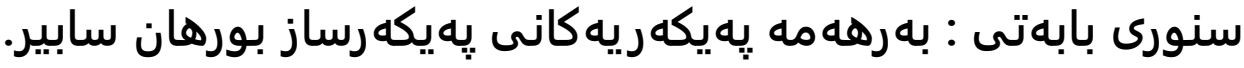

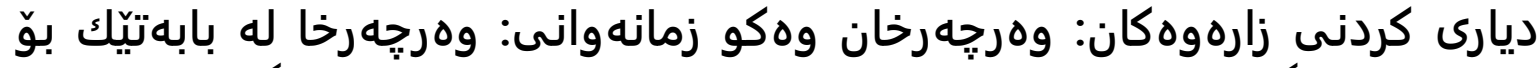

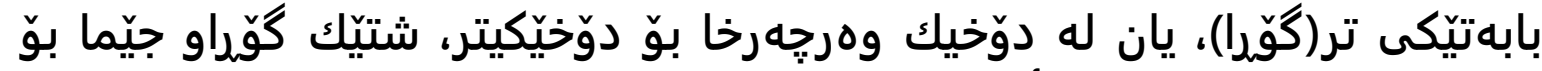

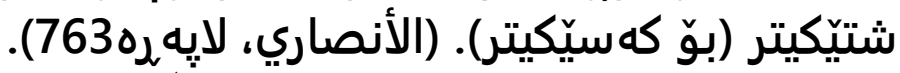

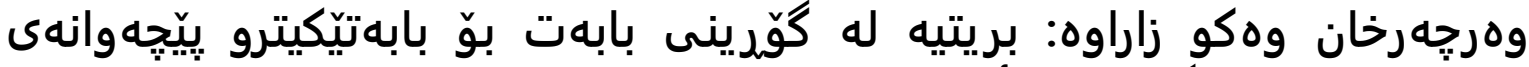

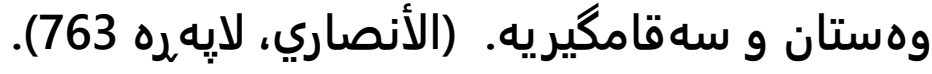

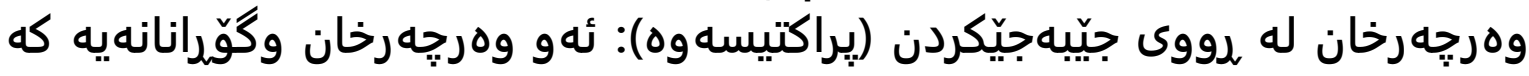

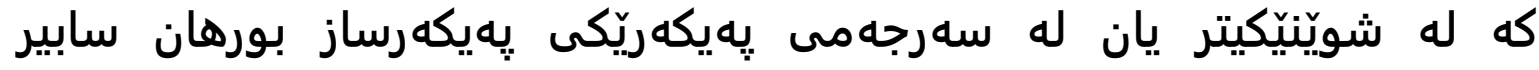

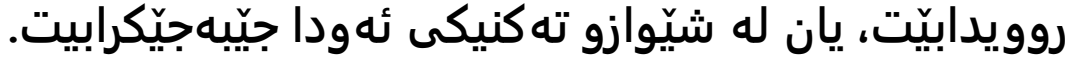

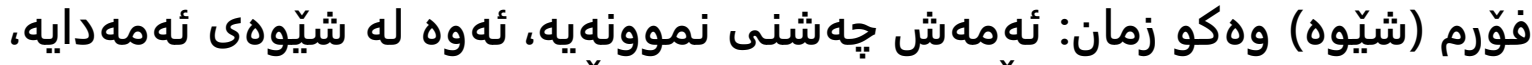

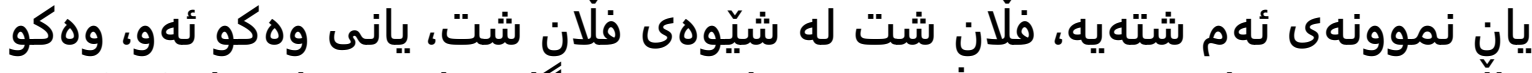

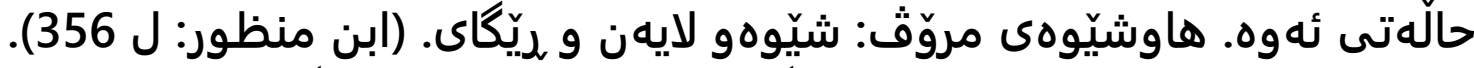

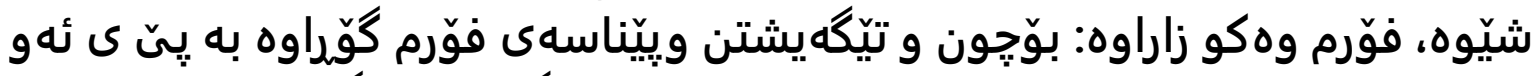

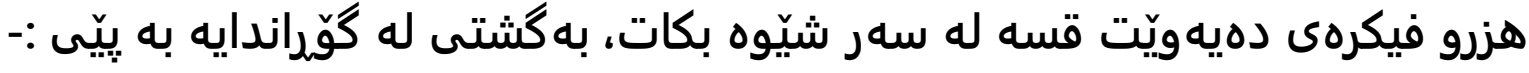


سروشتى ههر فهلسه فهو فيكرو قسهكه رو فهيلهسوفيّك كه كردويهتى به بابهتى

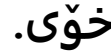

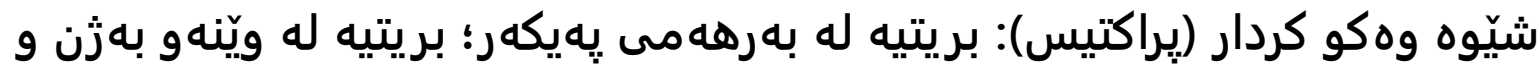

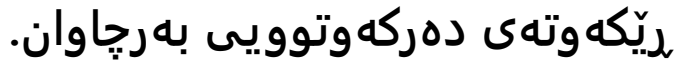

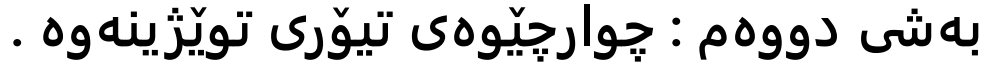

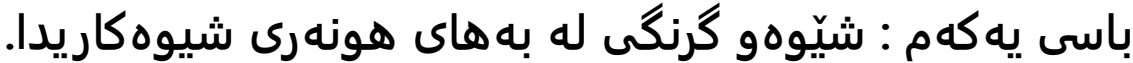

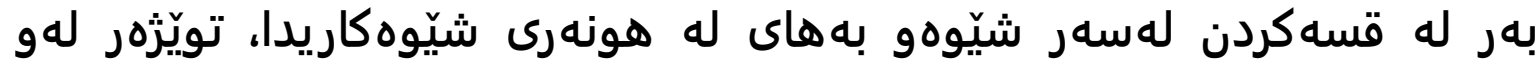

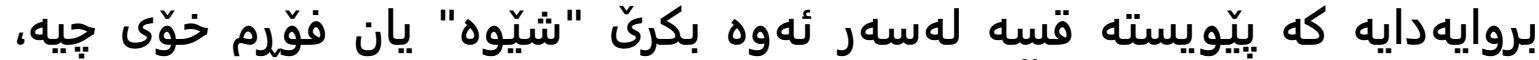

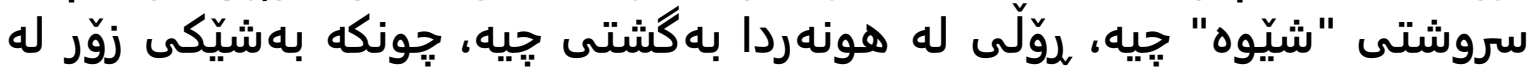
فهيلهسوفهكان و تيئوّرزانهكان ناكوّكن لهسهو

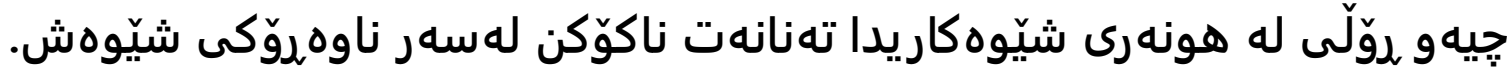

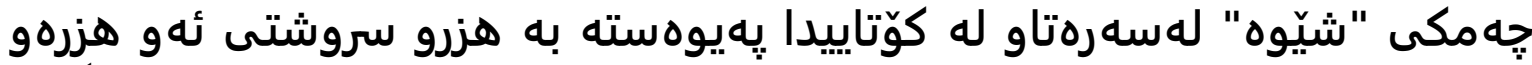

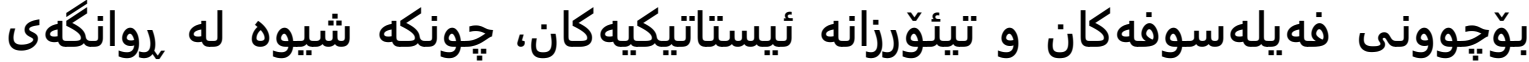

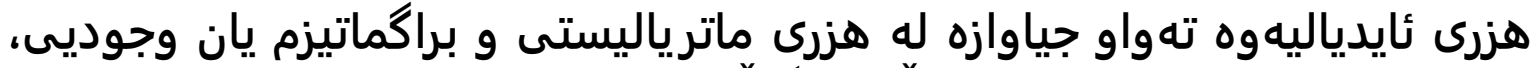

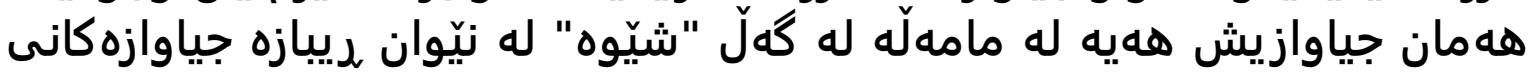

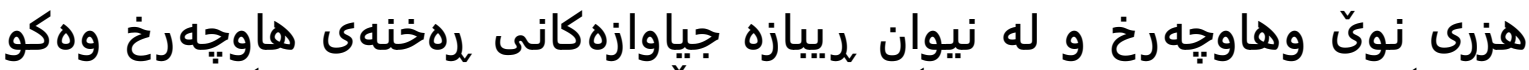

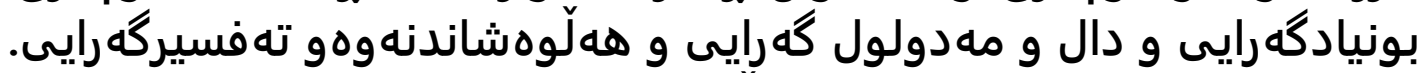

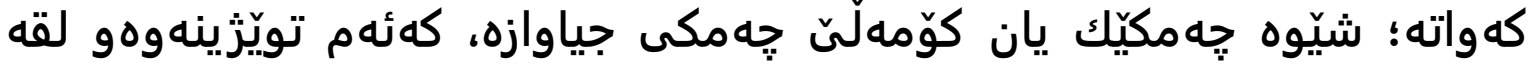

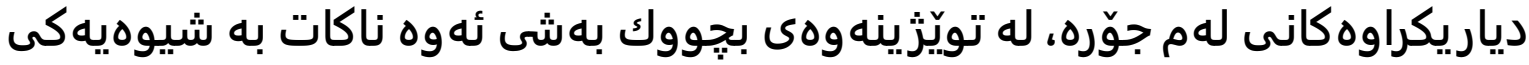

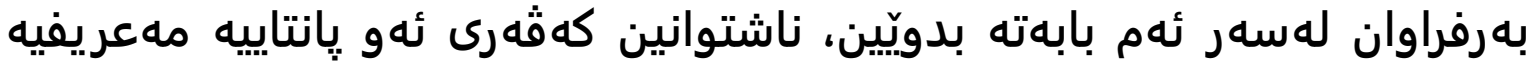

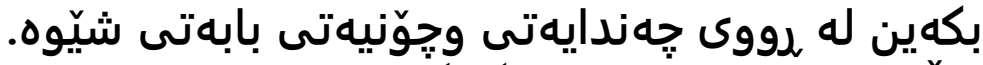

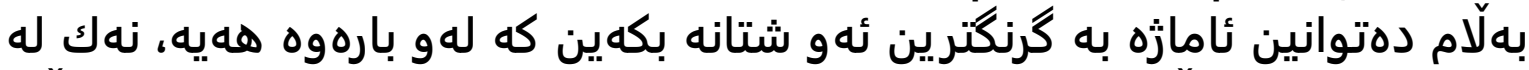

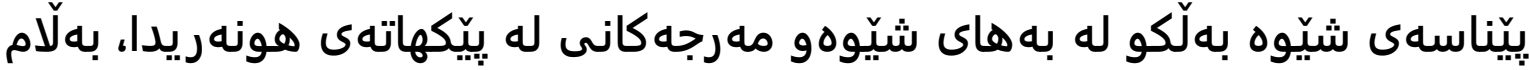

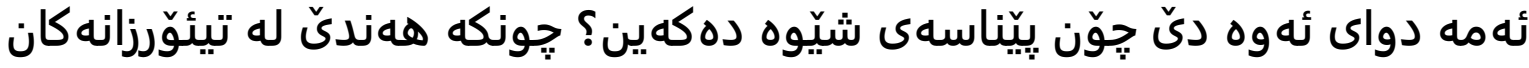

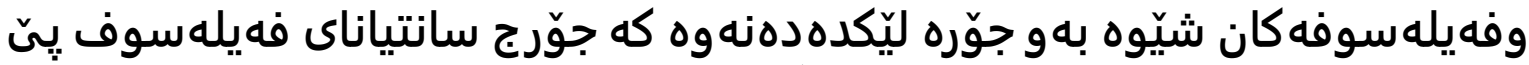

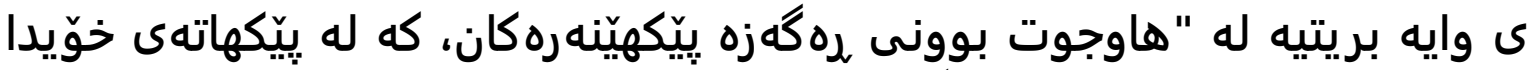

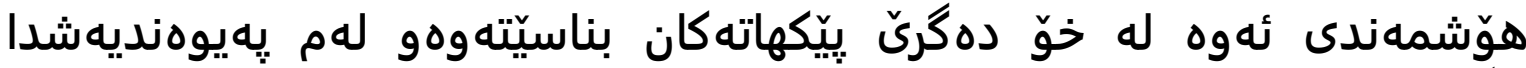
تيّكهيشتن له شيَّوهو هه

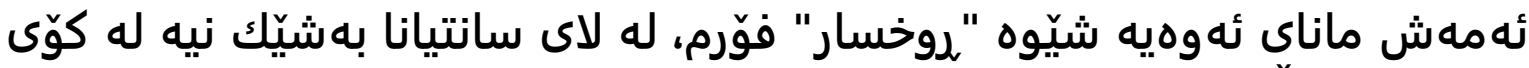

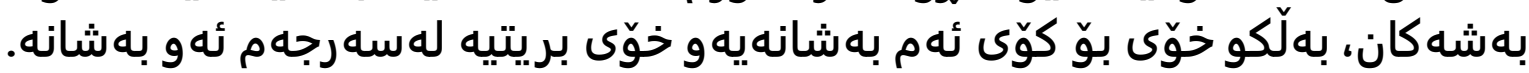




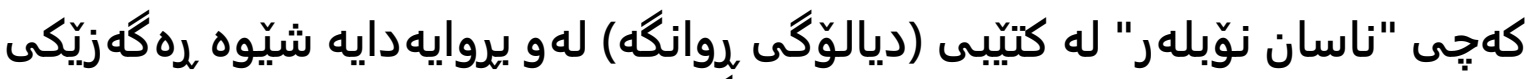

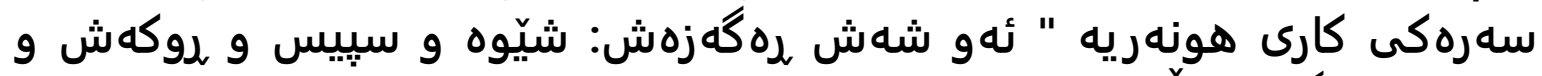

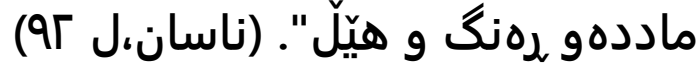

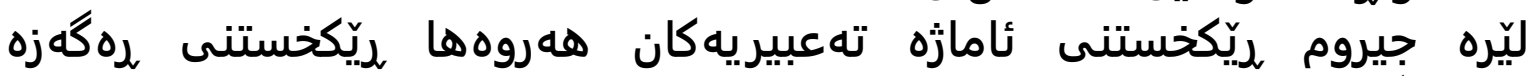

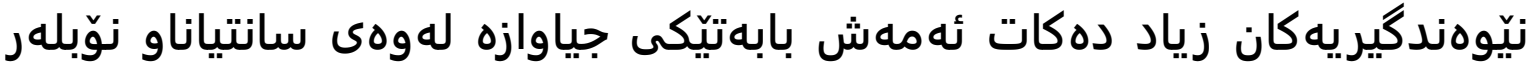

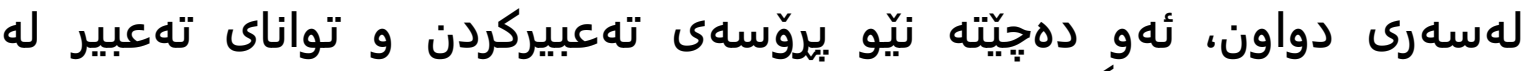

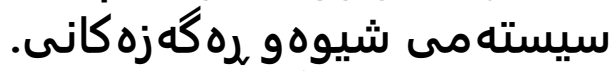

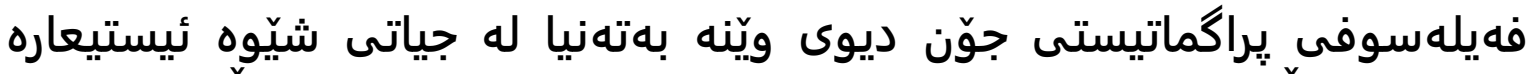

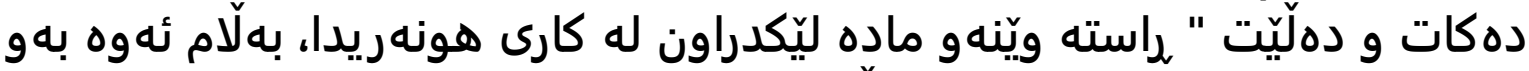

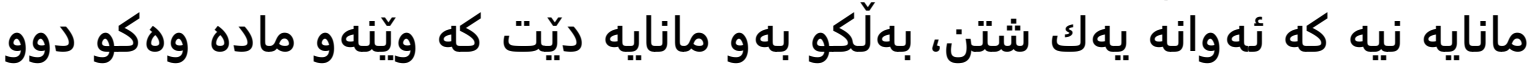

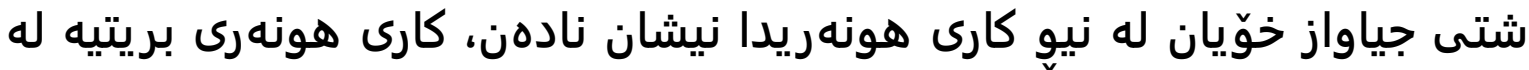

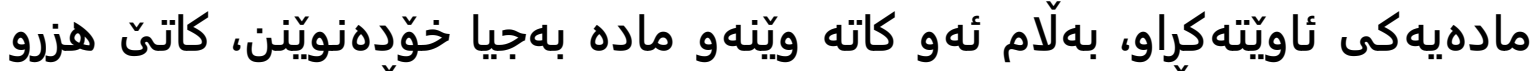

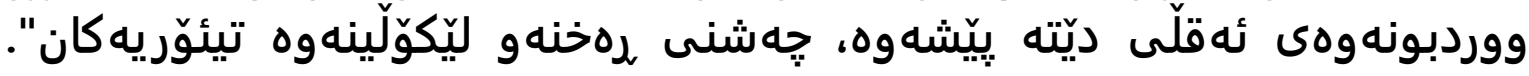

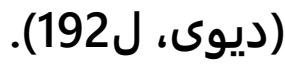

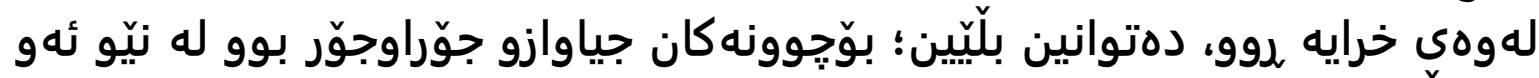

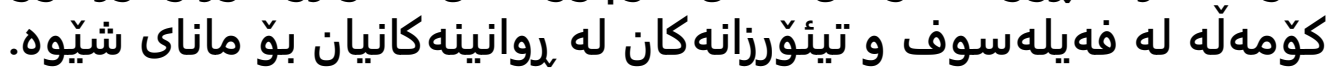

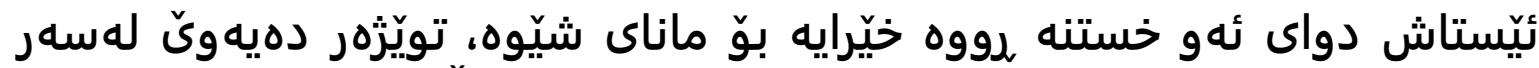

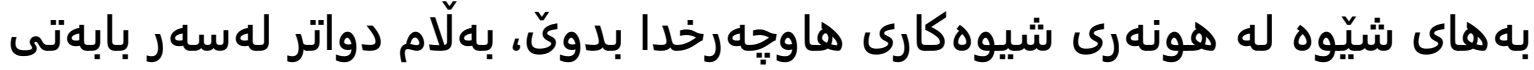

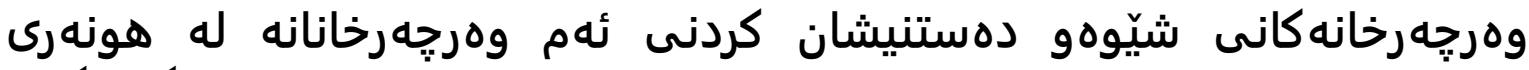

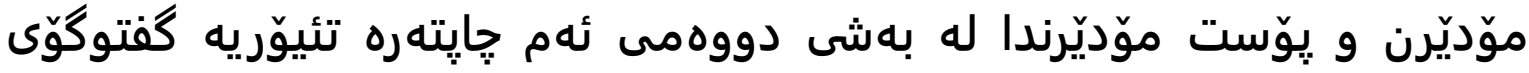

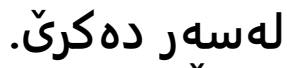

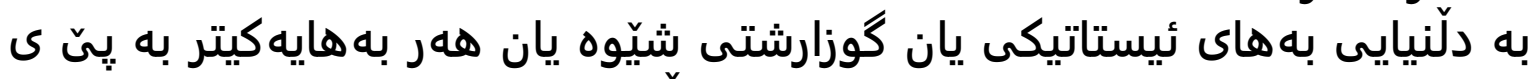

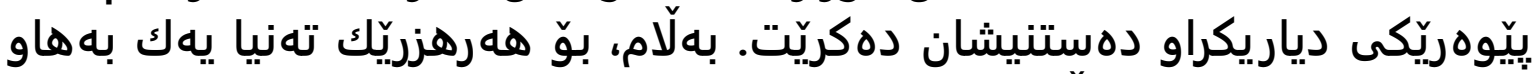

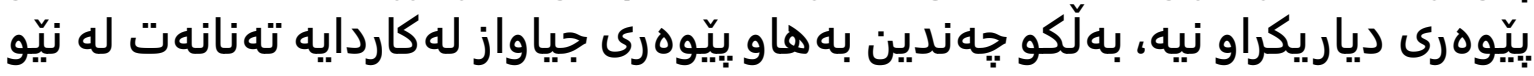

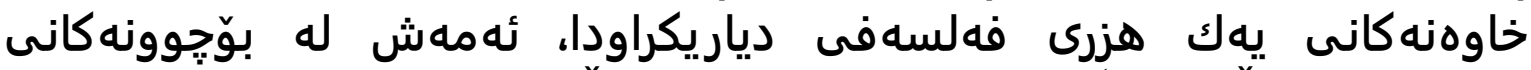

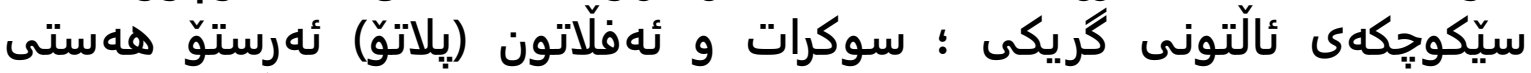

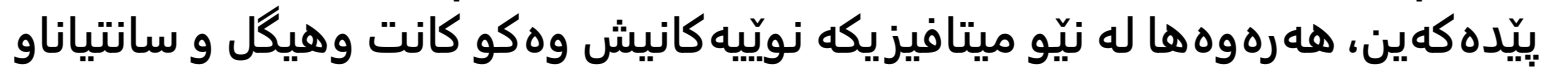

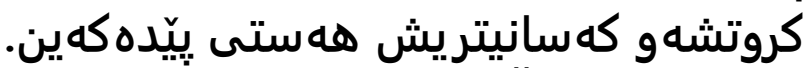

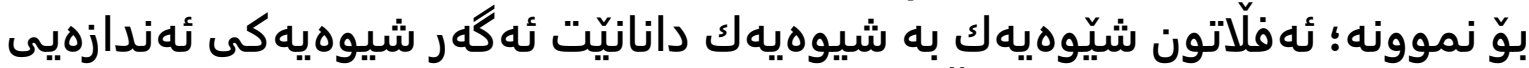

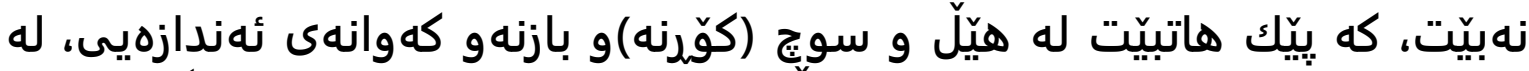

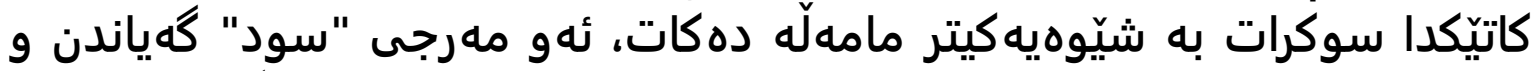

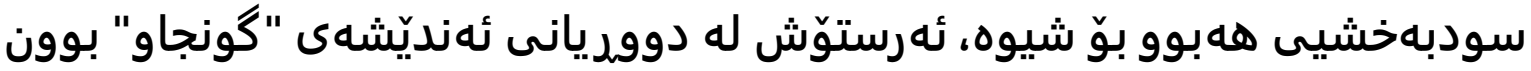




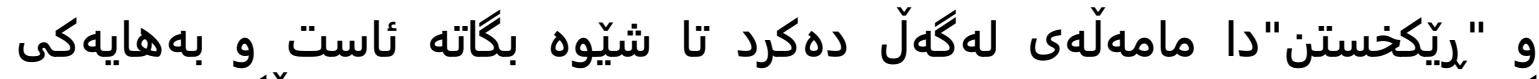

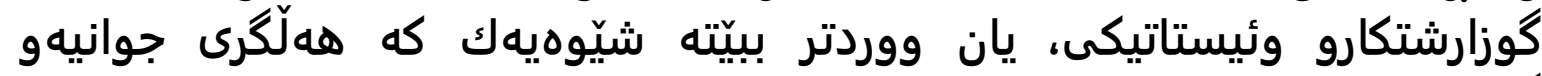
كوزارشت له جوانى دهكا.

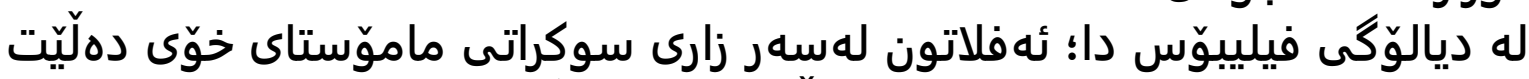

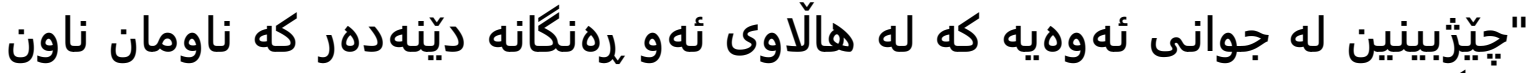

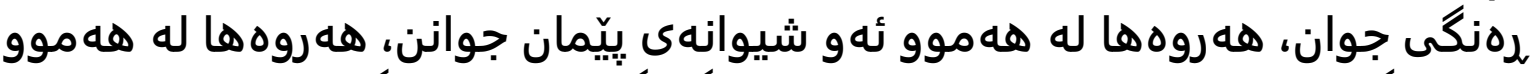

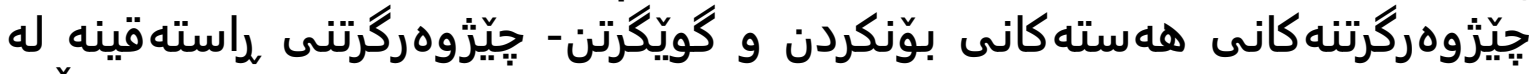

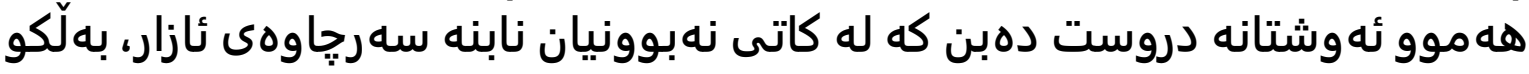

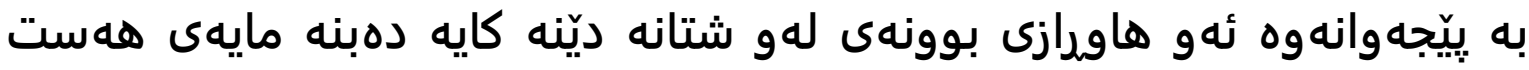

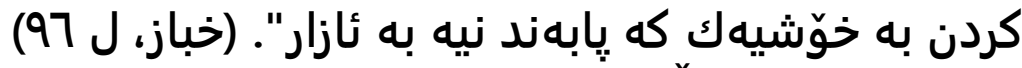

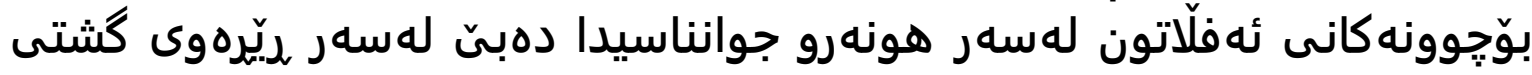

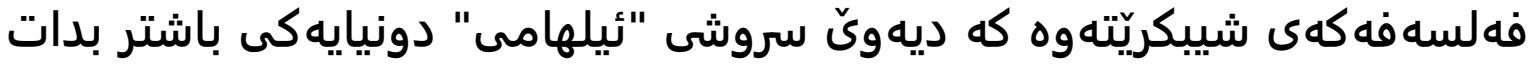

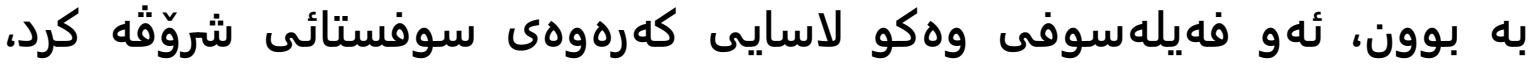

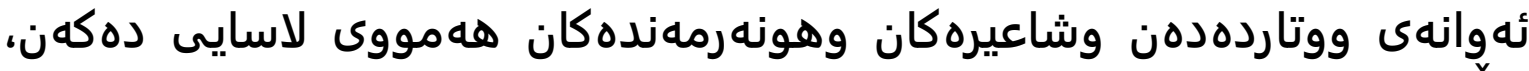

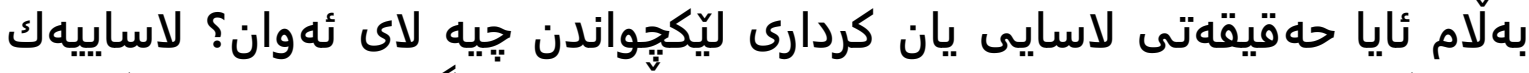

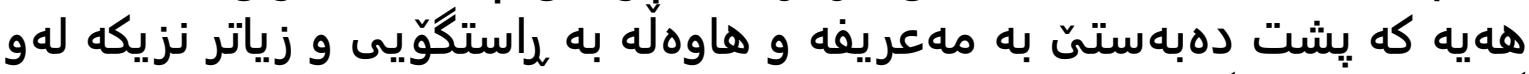

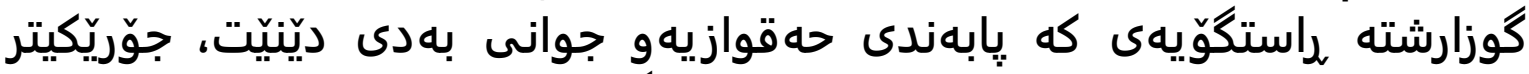

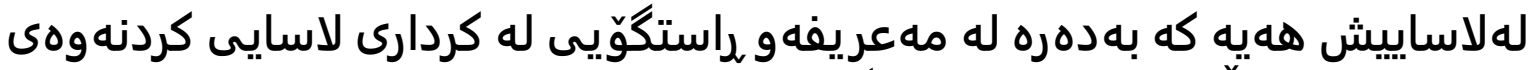

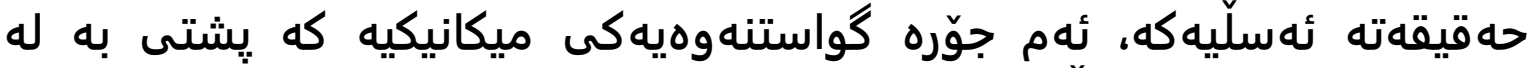

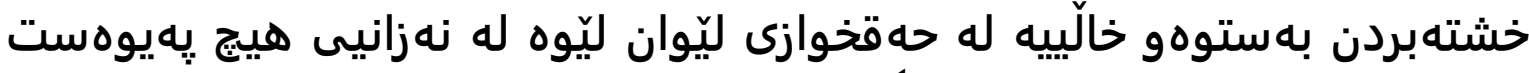

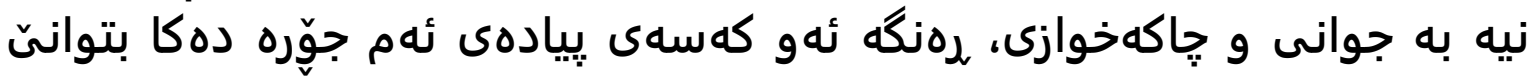

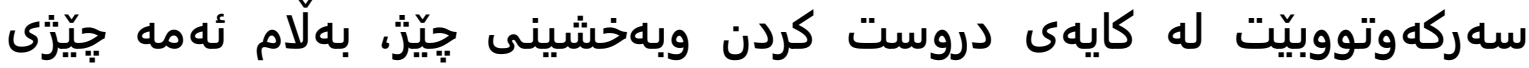

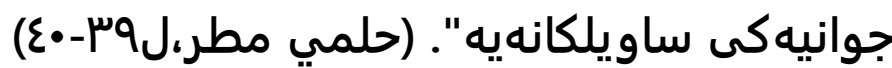

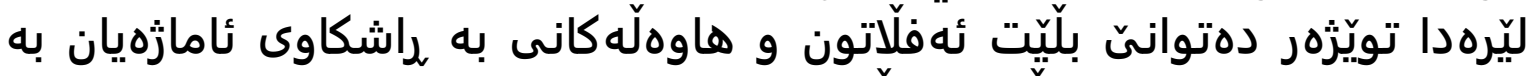

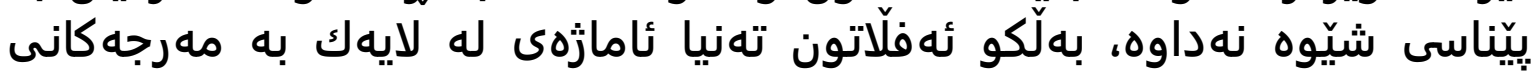

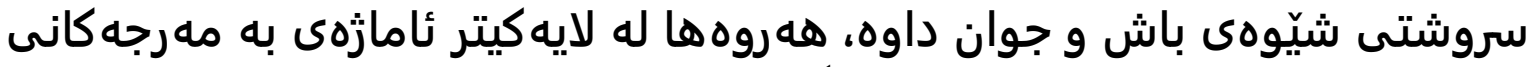

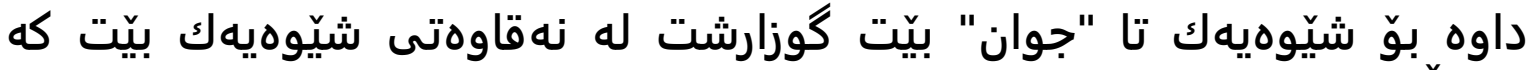

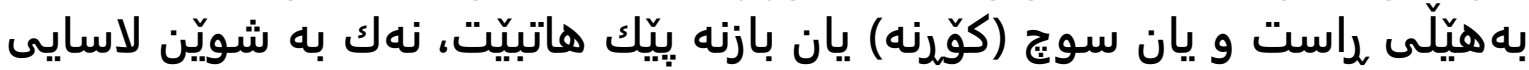

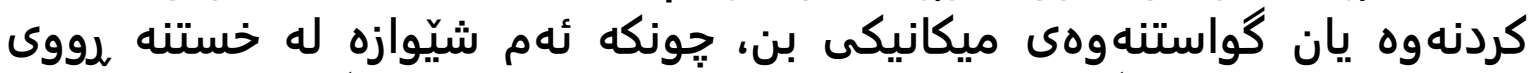

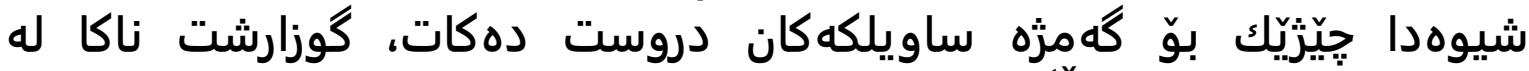

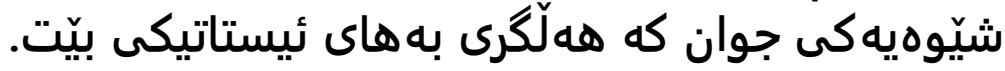




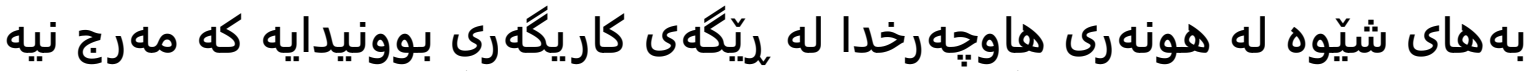

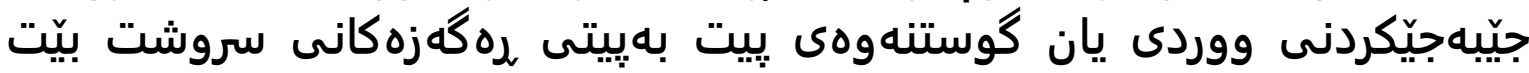

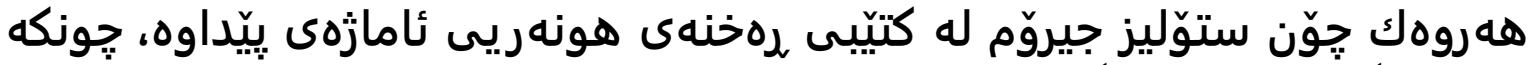

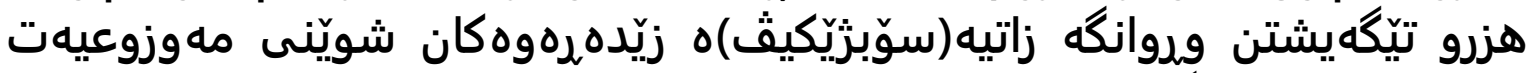

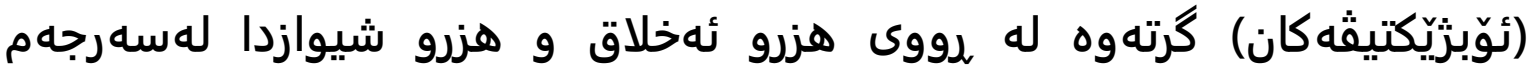

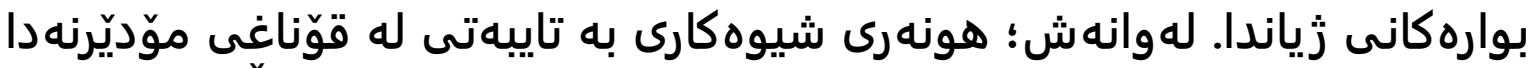

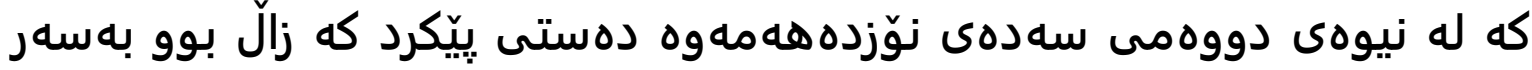

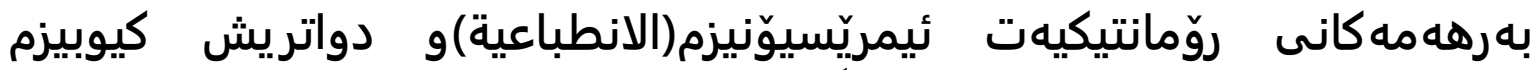

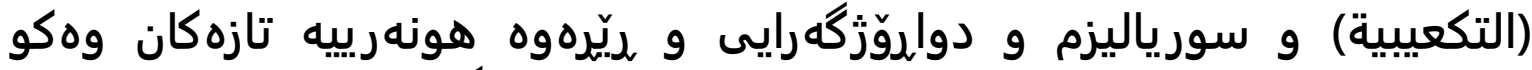

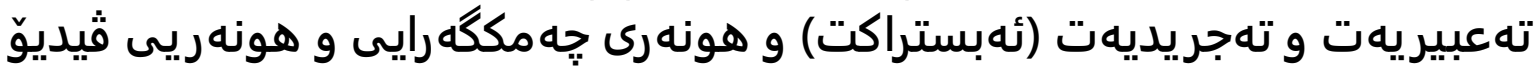

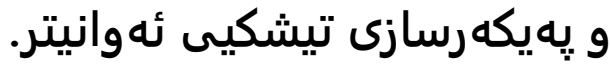

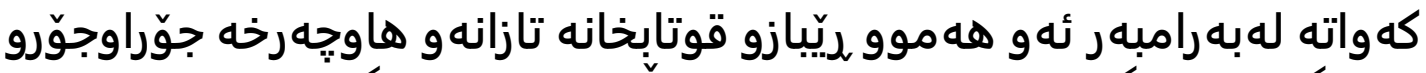

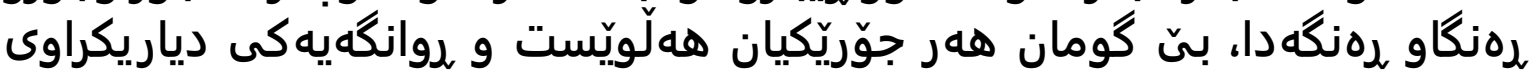

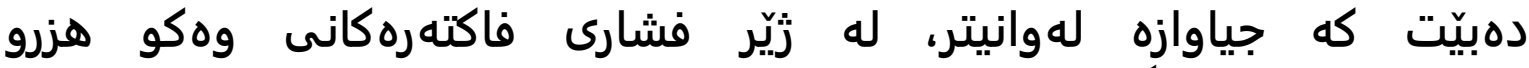

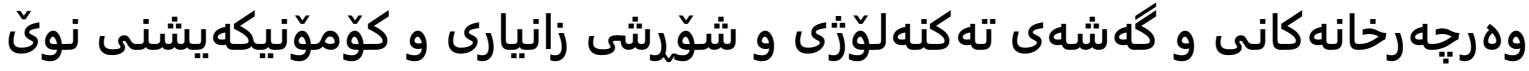

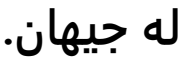

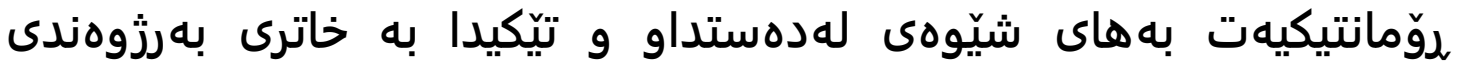

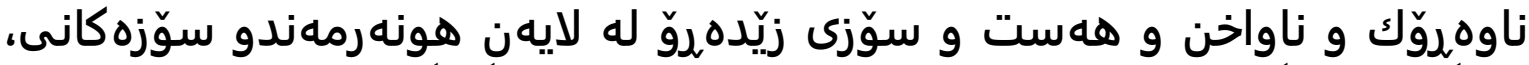

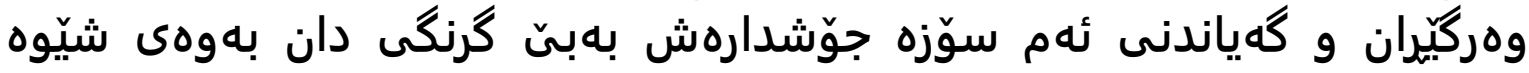

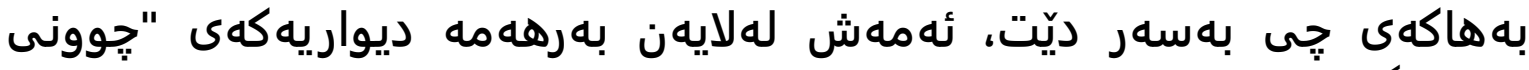

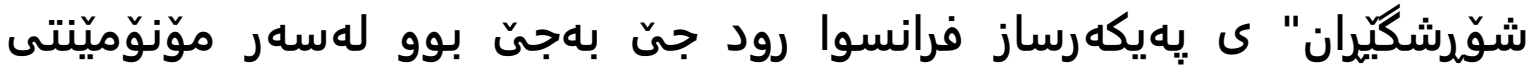

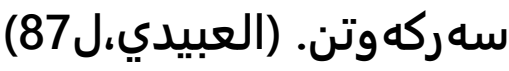

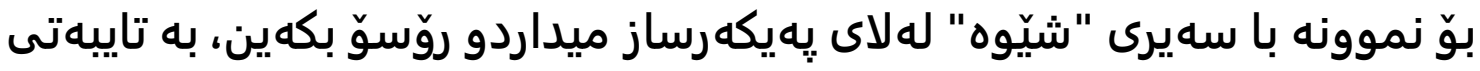

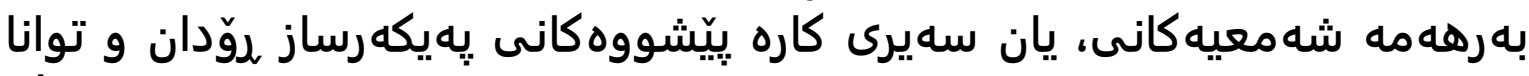

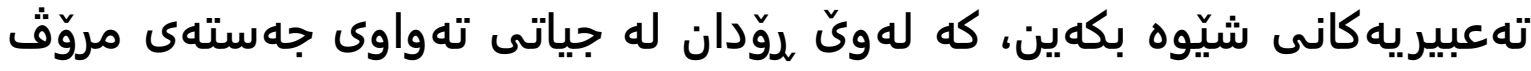

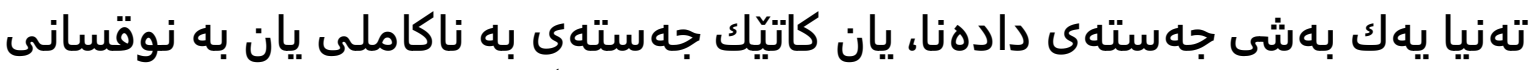

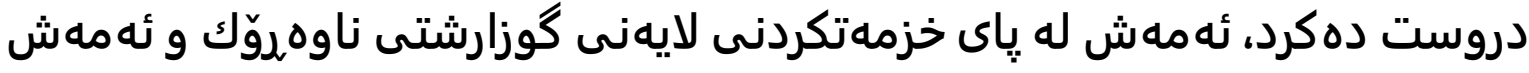

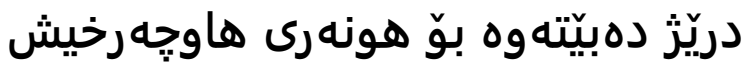

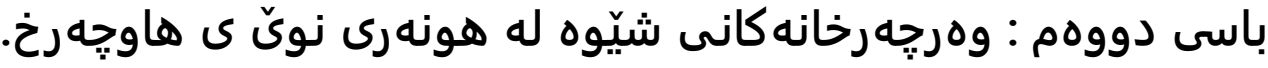

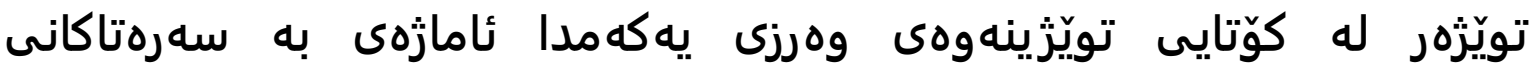

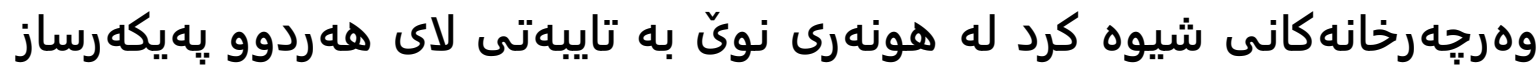

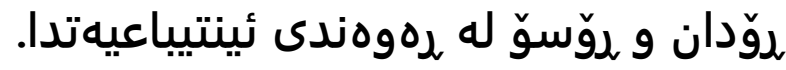




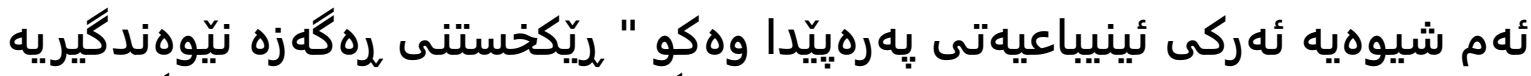

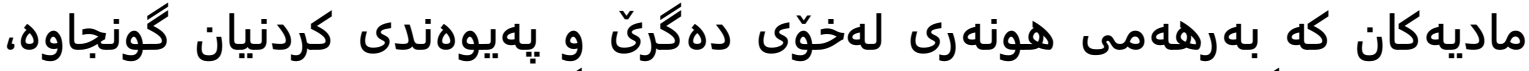

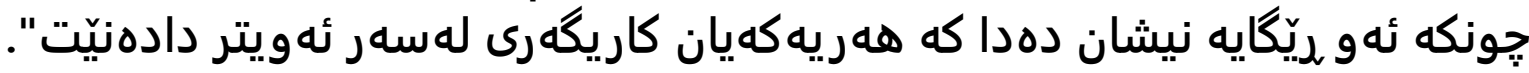

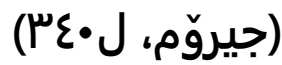

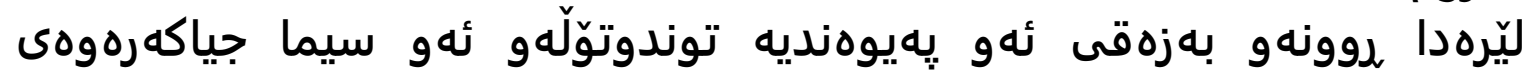

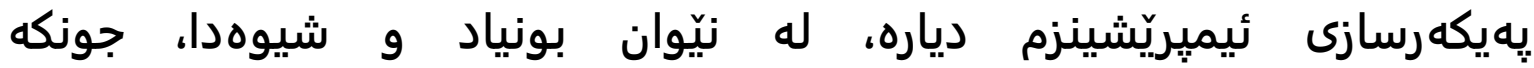

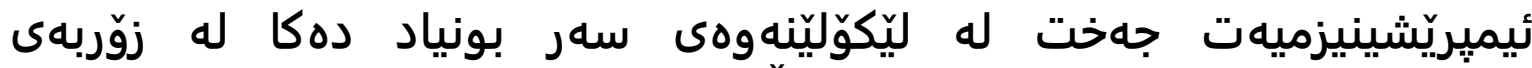

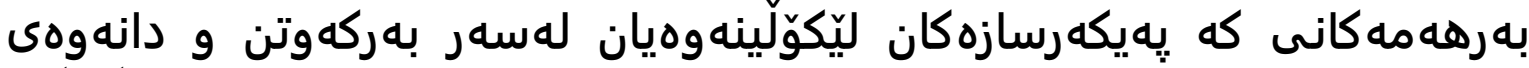

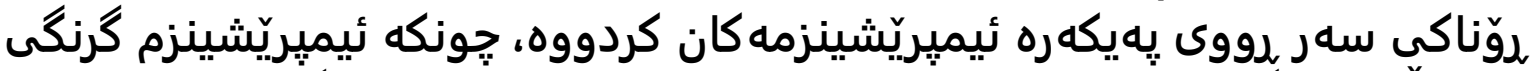

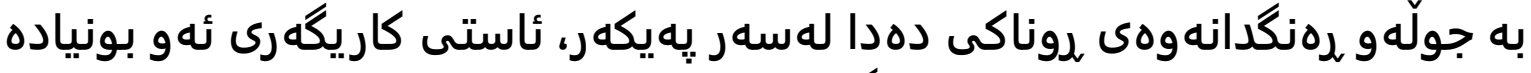

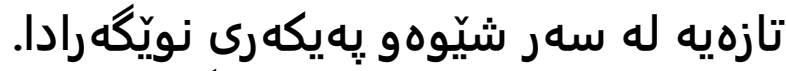

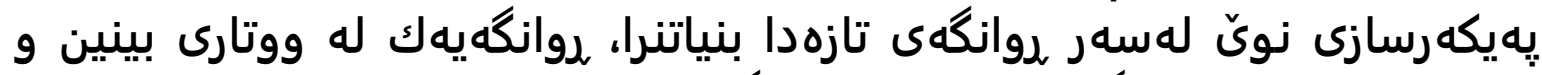

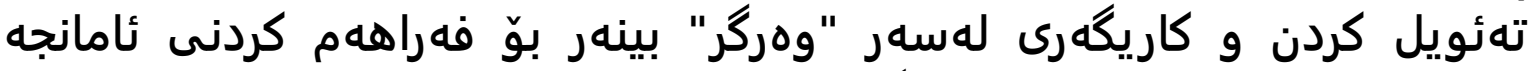

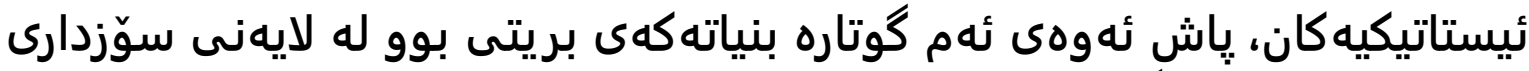

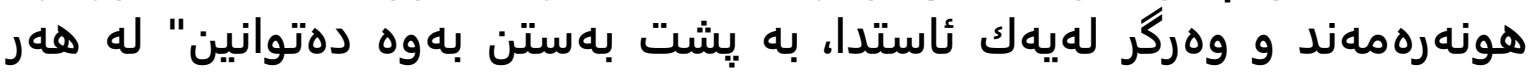

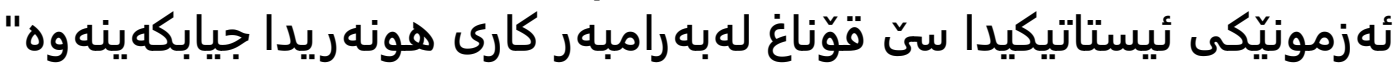

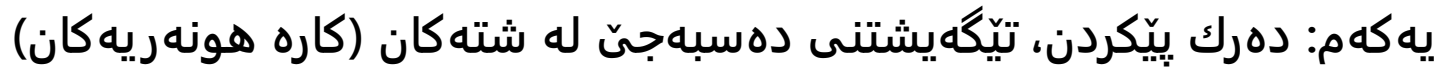

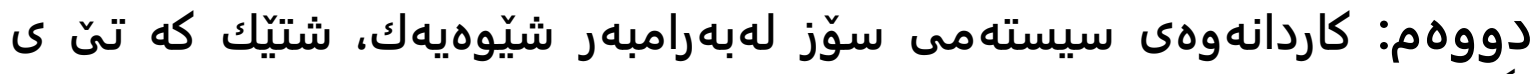
بكات.

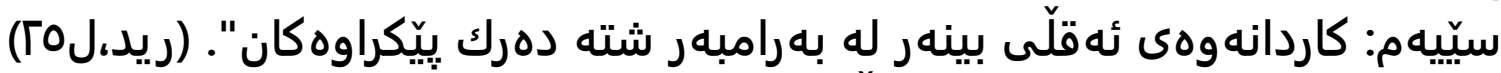

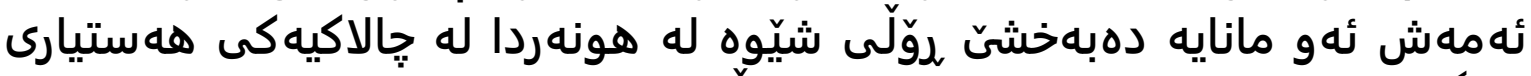

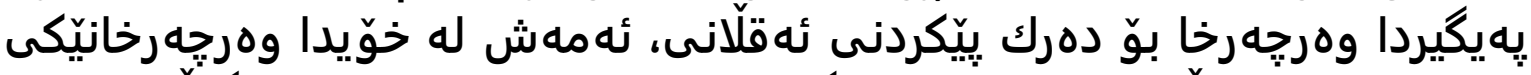

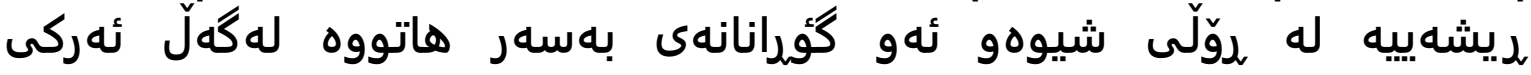

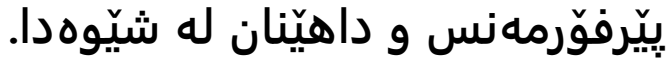

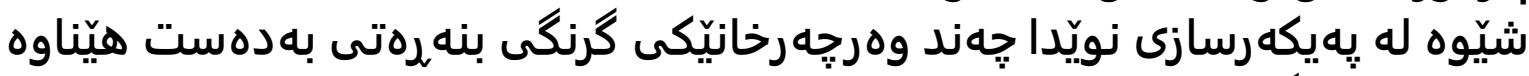

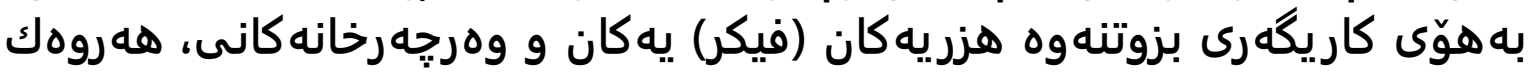

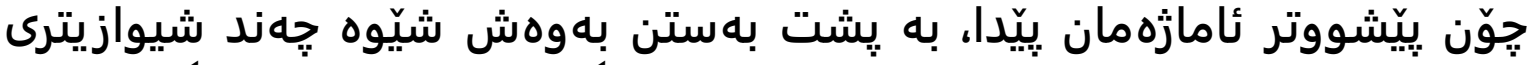

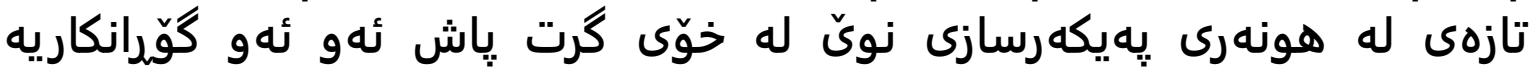

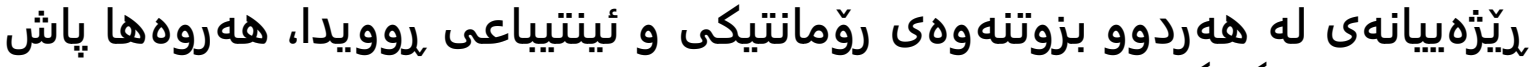

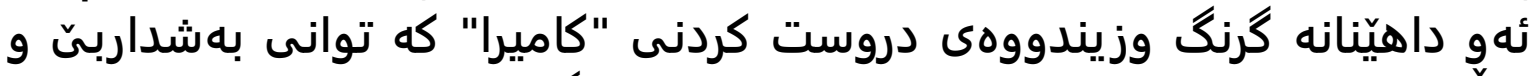

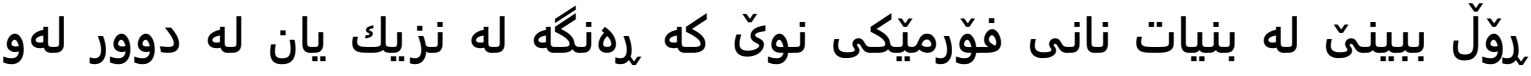

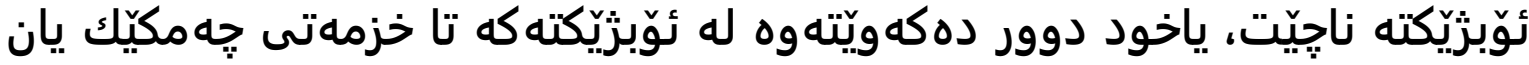




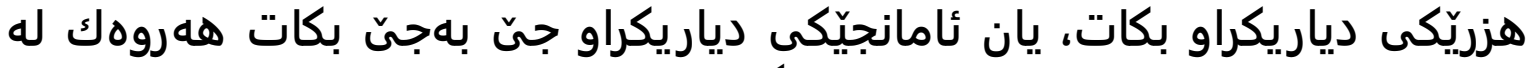

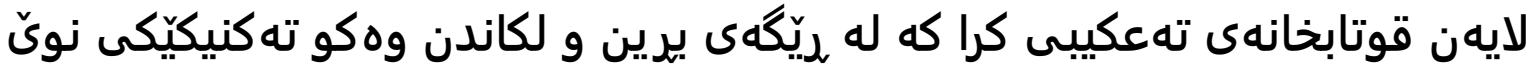

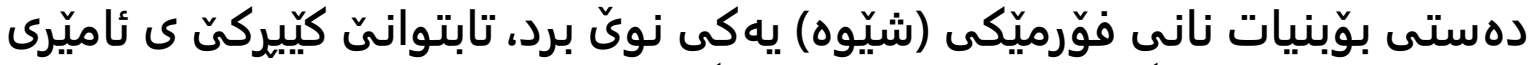

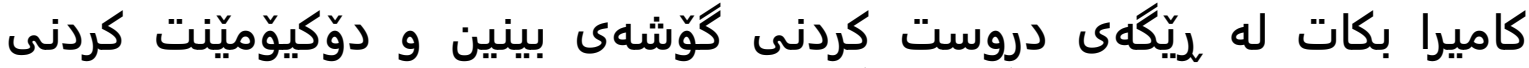

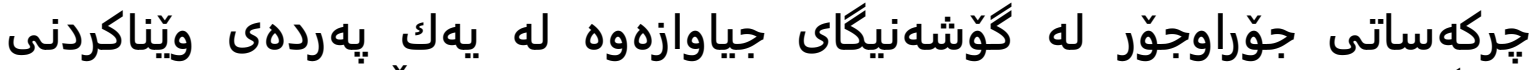

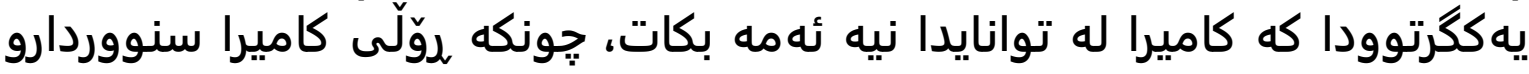

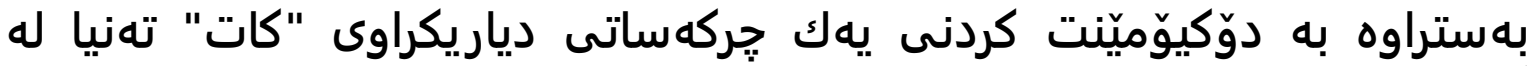

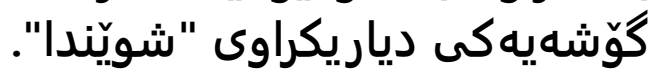

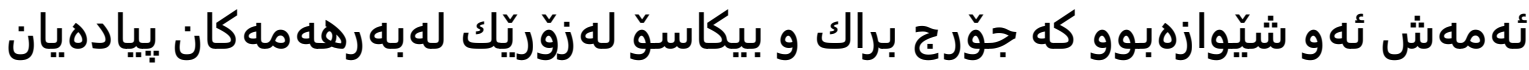

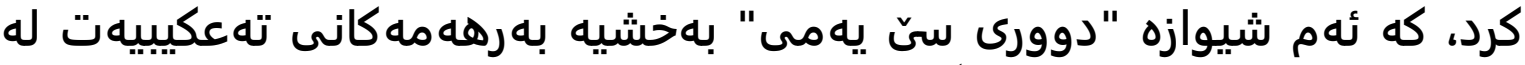

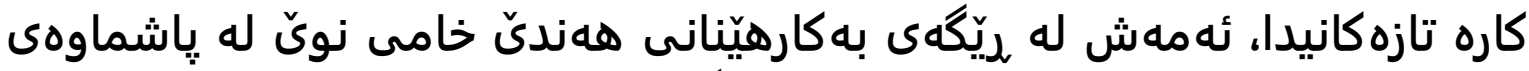

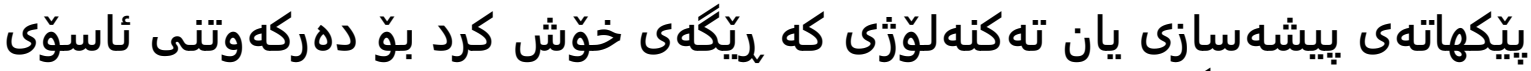

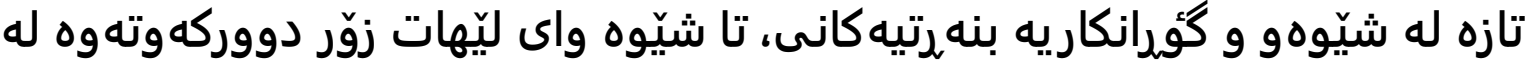

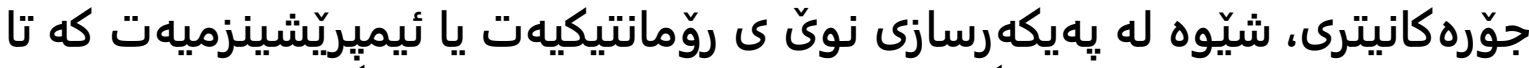

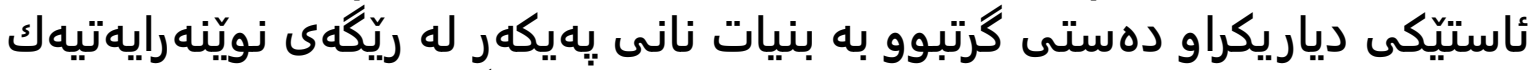

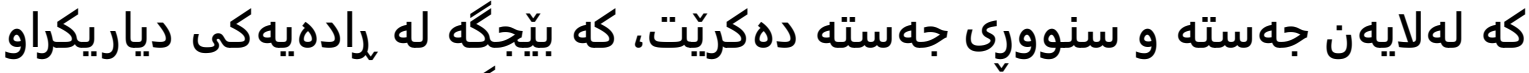

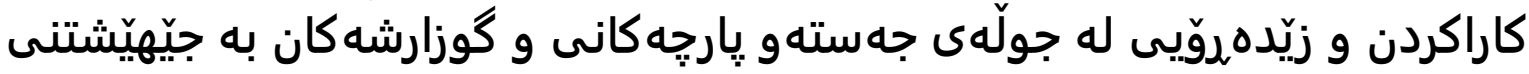

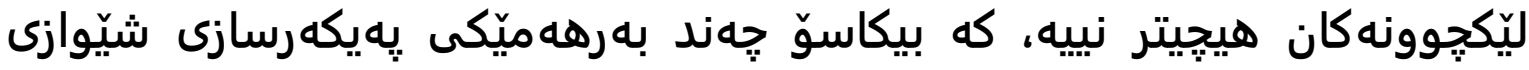

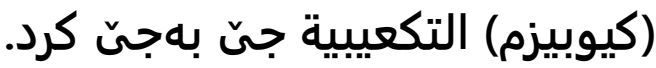

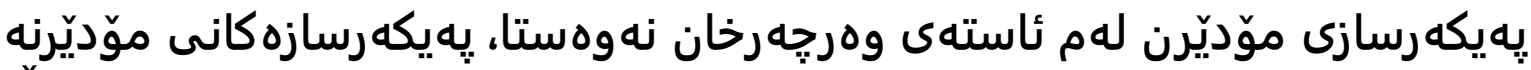

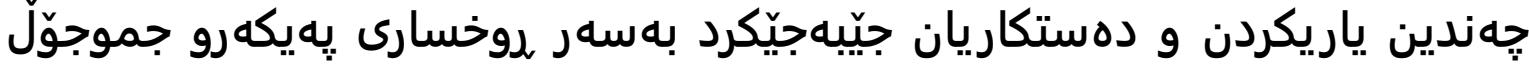

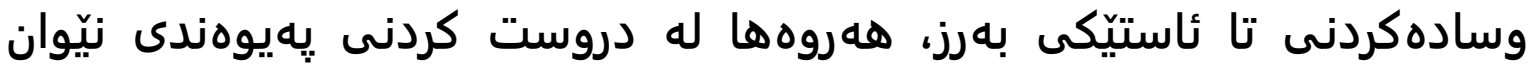

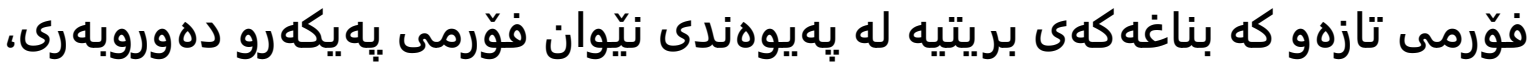

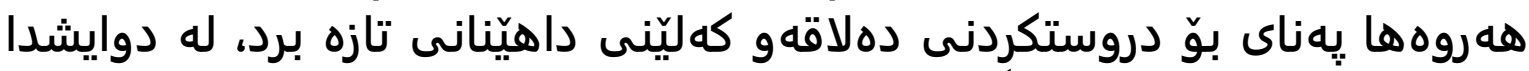

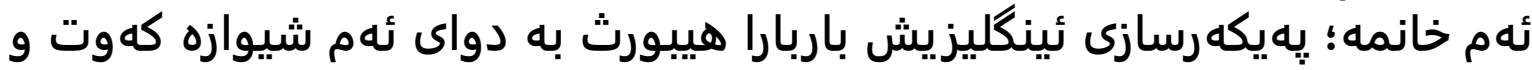

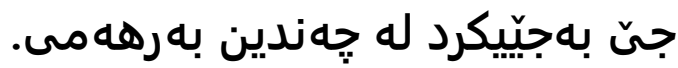

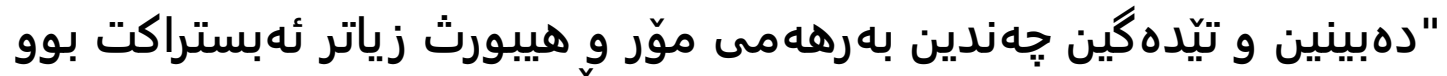

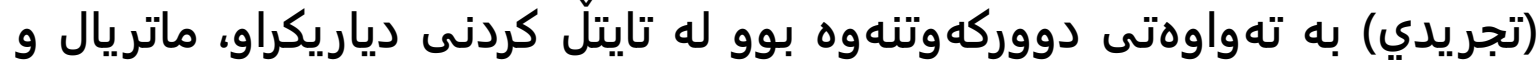

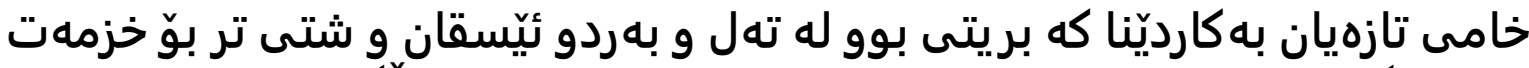

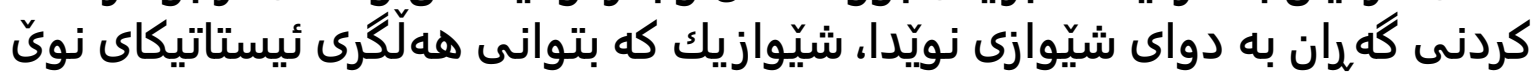

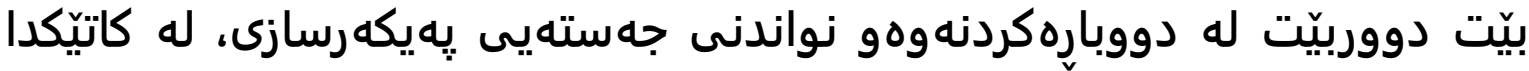

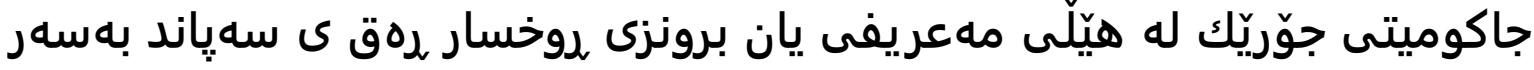




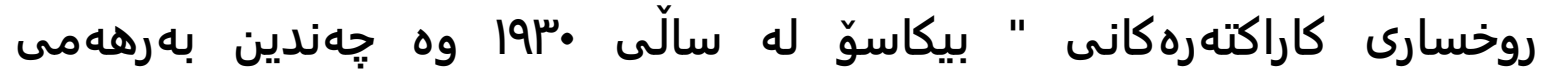

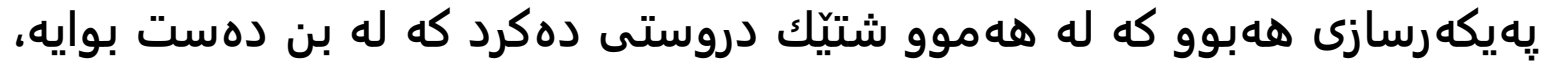

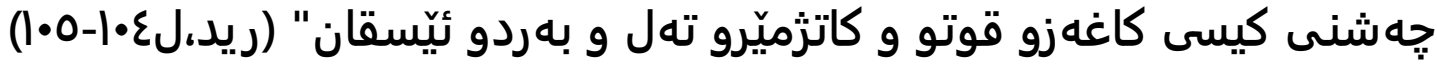

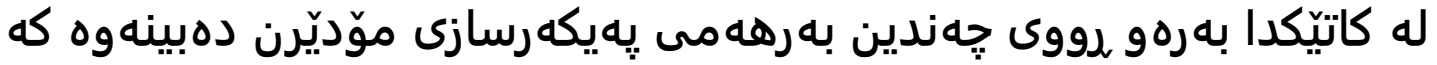

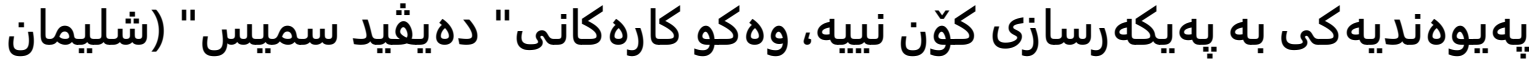

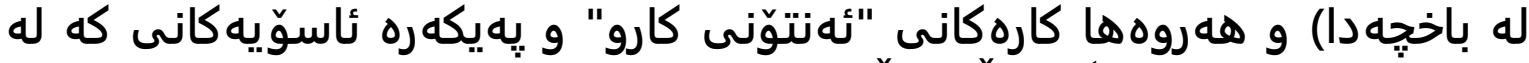

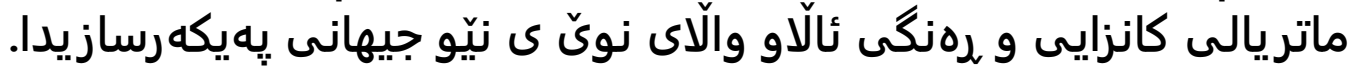

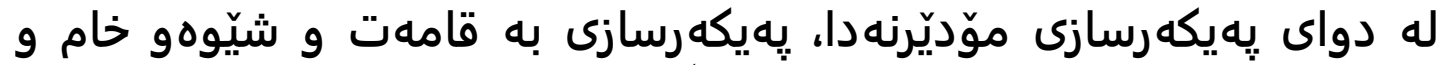

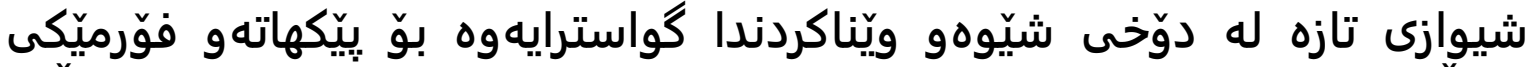

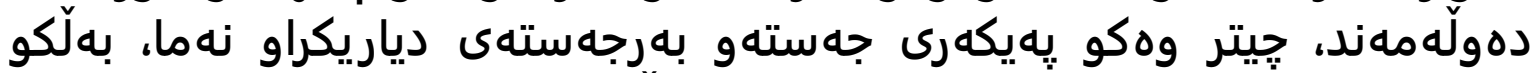

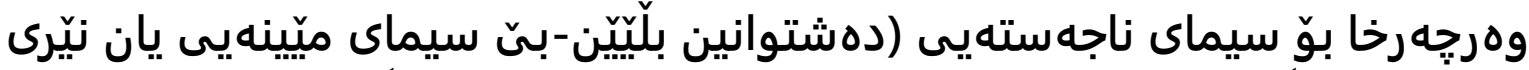

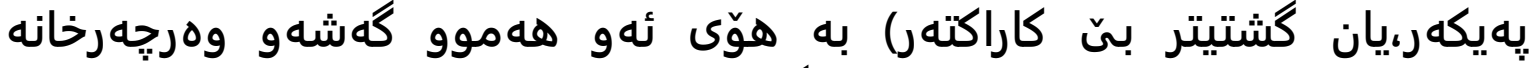

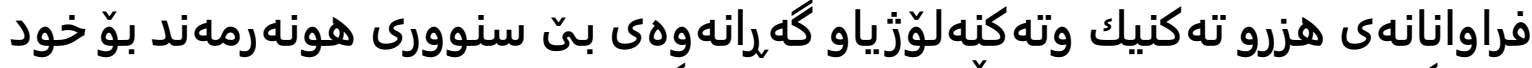

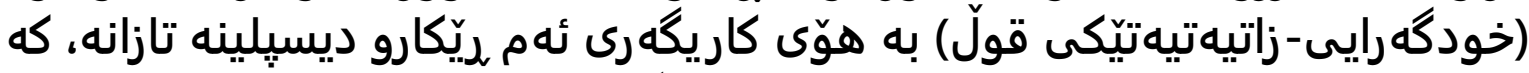

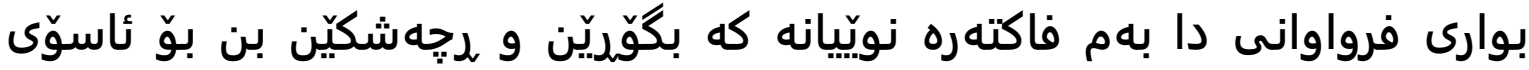

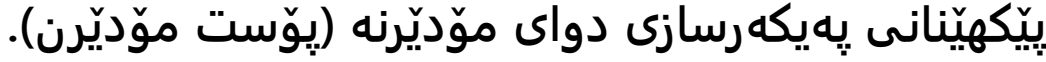

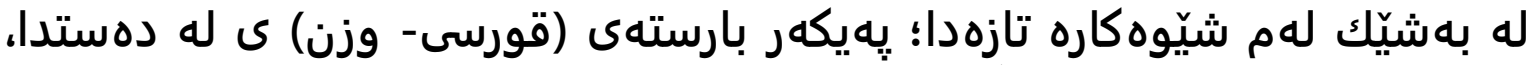

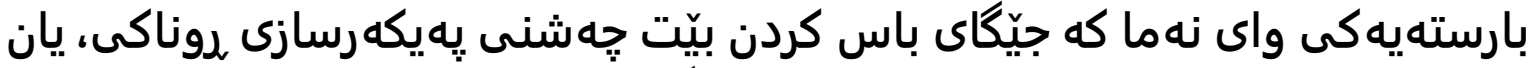
سيماى كاراكته رى له دهستداو وهريه رخانه

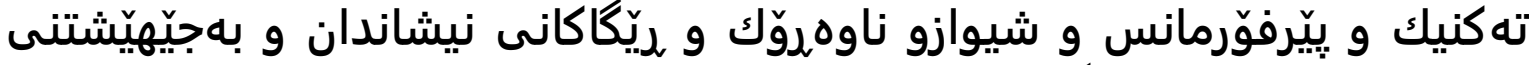

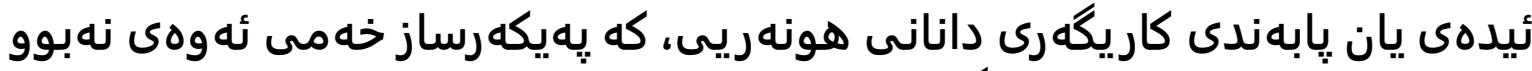

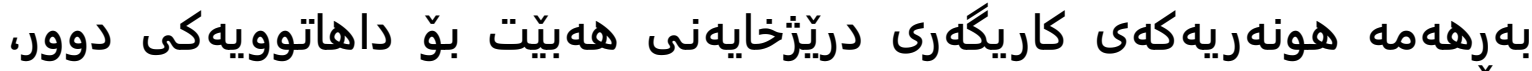

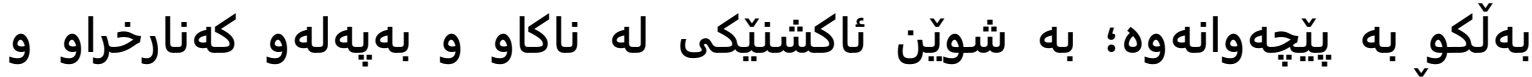

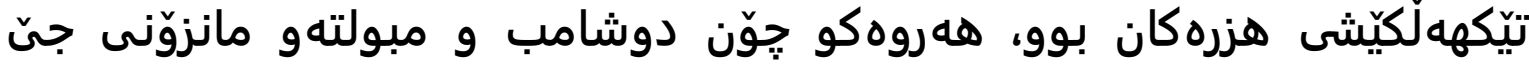

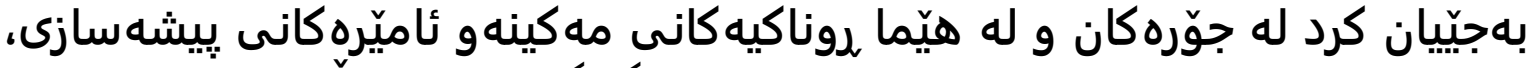

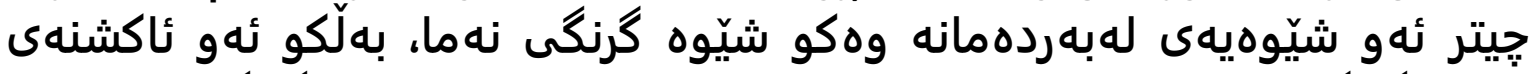

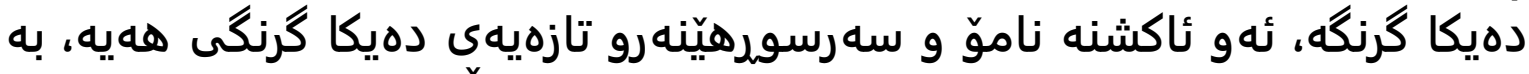

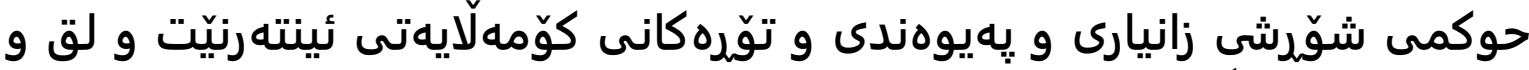

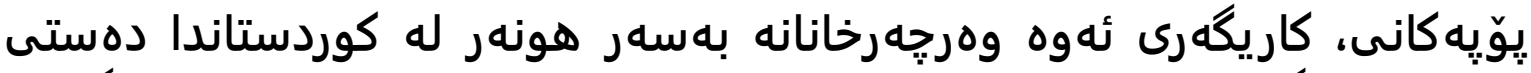

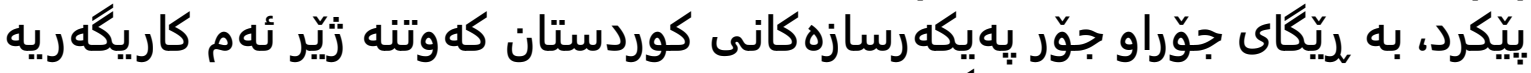

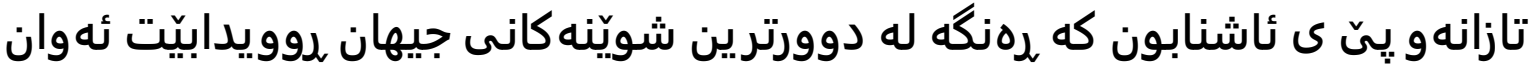


ليَره له شارهكانى خوّيان بهدواجِوونيان بوّ كردبيّت له ريّكَاى توَرهكانى يهيوهندى و توَره كانى ئينته رنيّيت.

\section{يِيِوهره ئامازَهكانى جِوارجيّيوهى تيوّرى :}

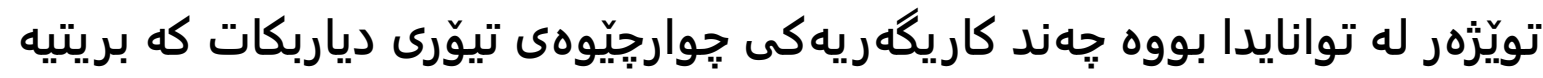

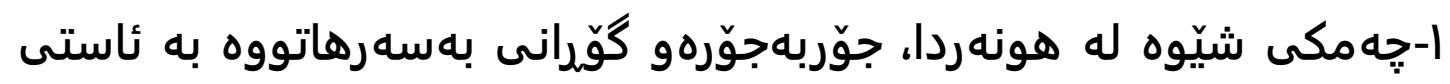

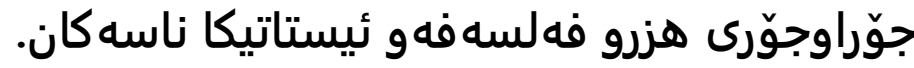

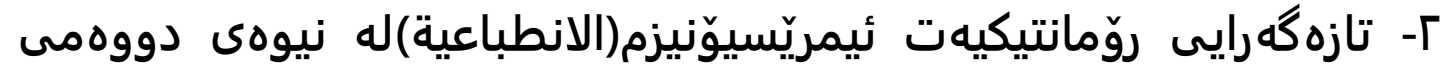

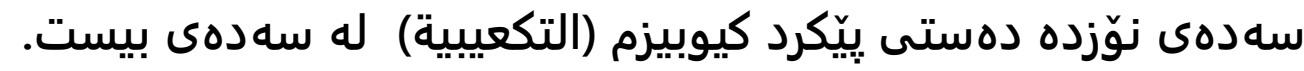

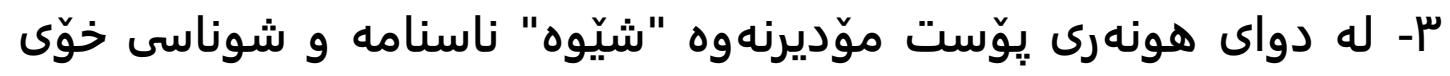
بهجيَهيْشت.

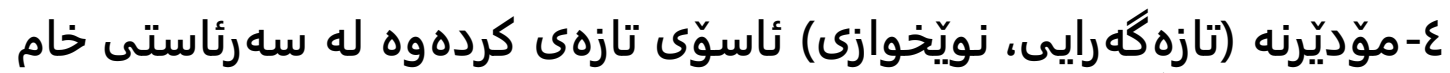

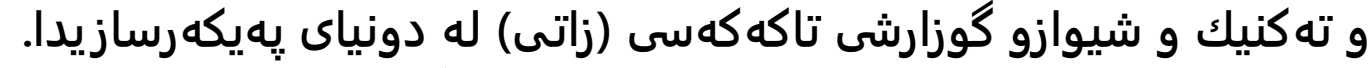

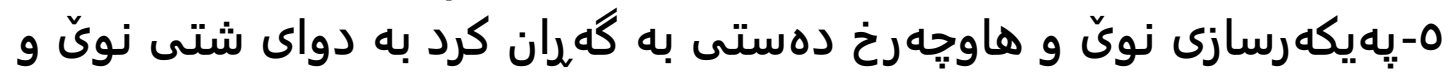

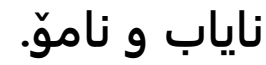

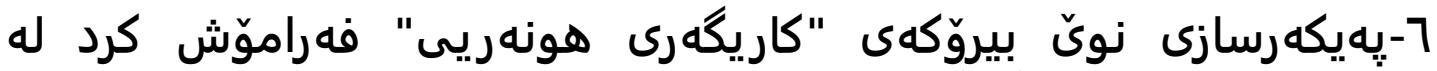

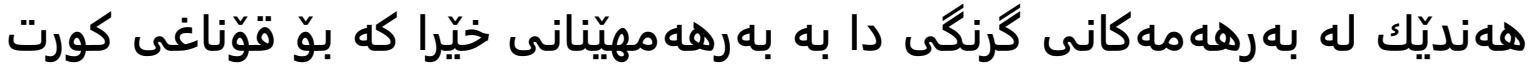

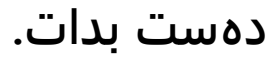

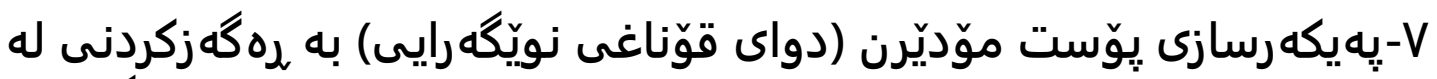

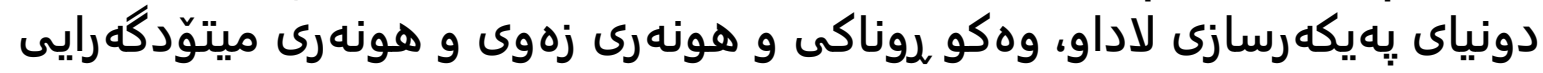
و ..هتد ليَهات.

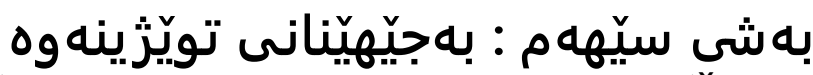

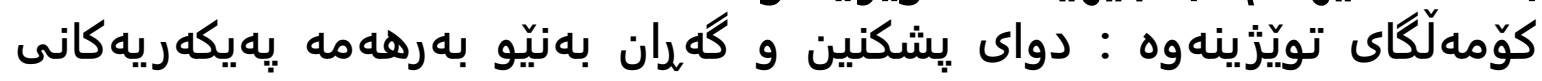

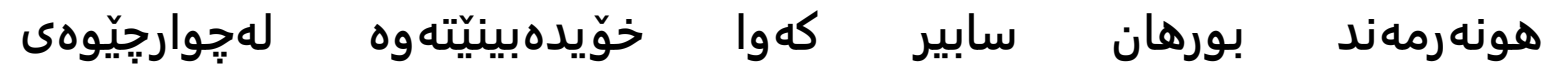

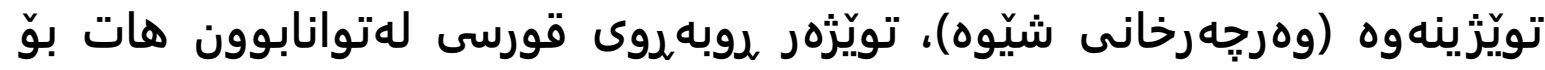

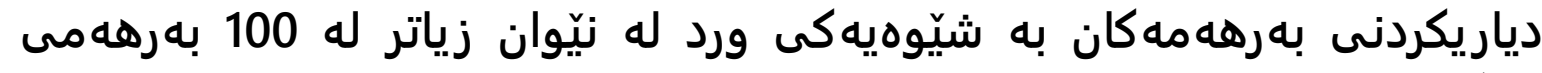

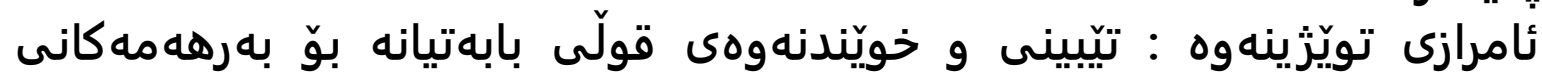

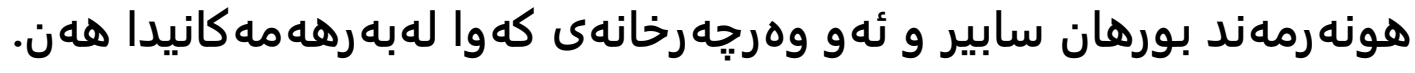




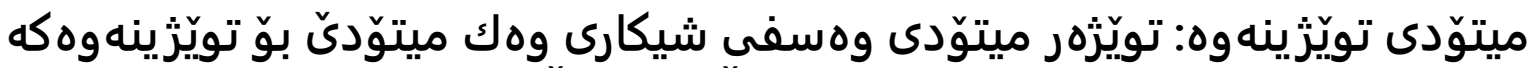

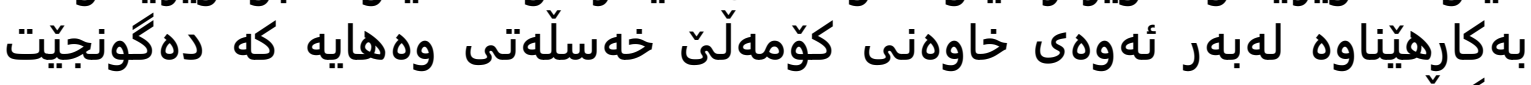

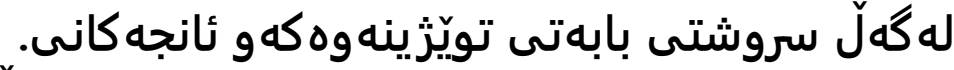

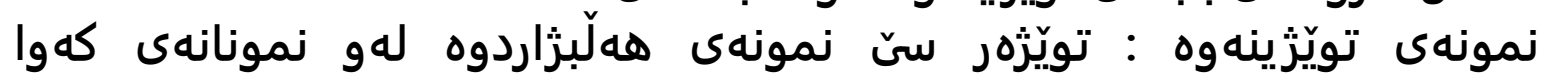

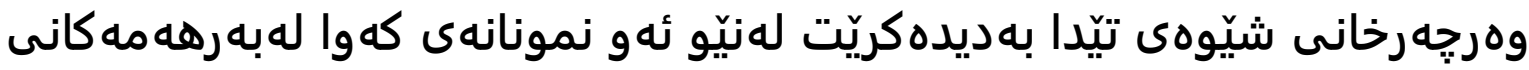

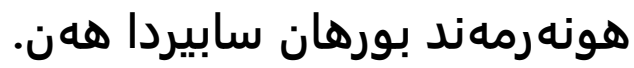

ليّكوَّلِينهوهى شيكارى بوّ شيَوهنمونه كانى تويَرْهر

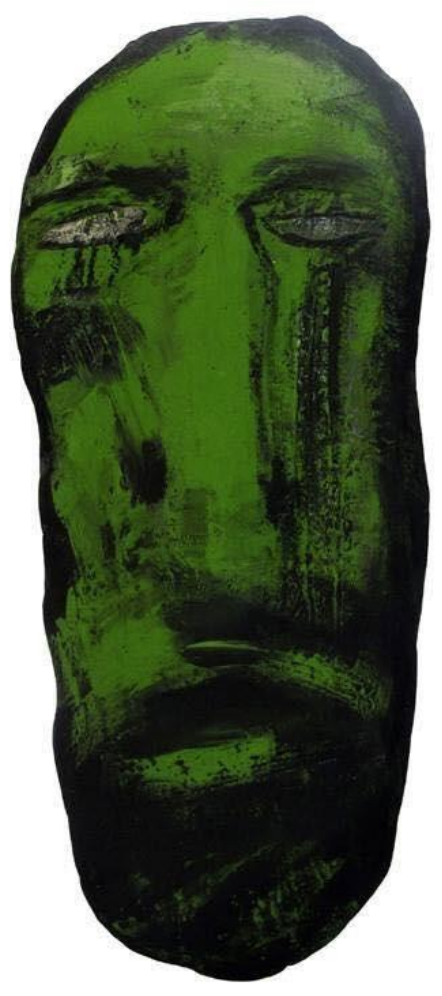

نمونه يه كهم

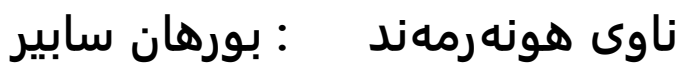

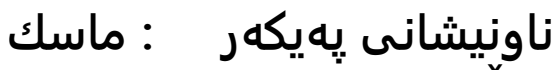
2004 : سالّى به رهه مهيّنانى بهانى

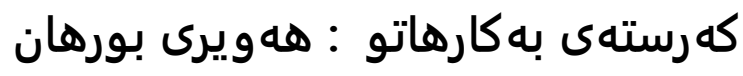

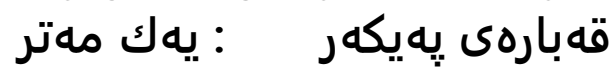




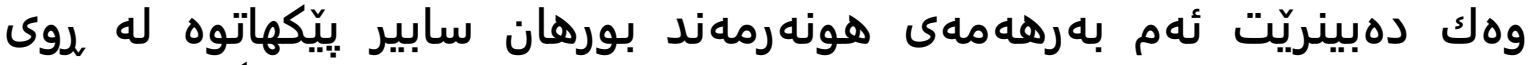

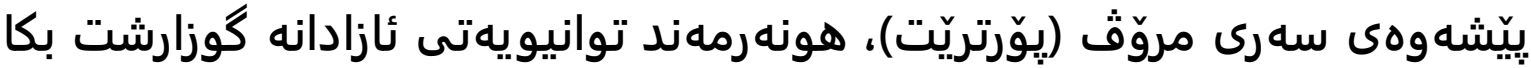

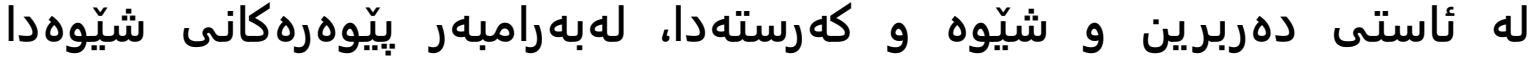

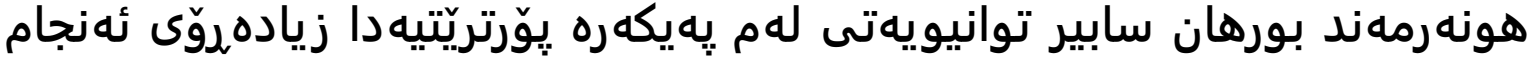

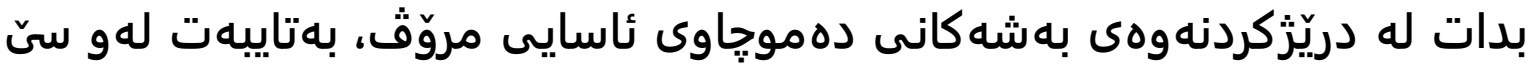

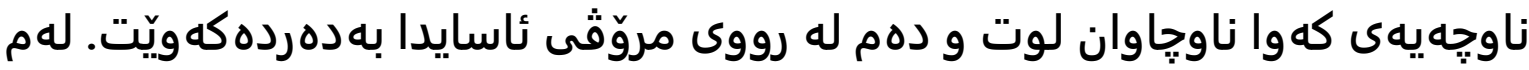

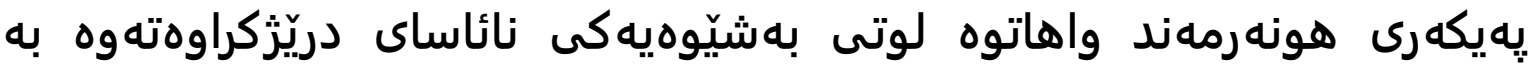

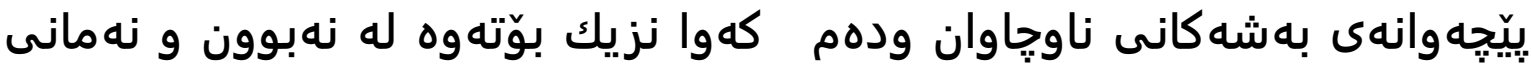

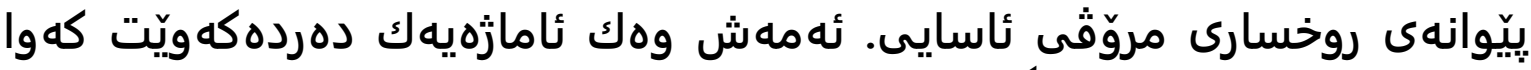

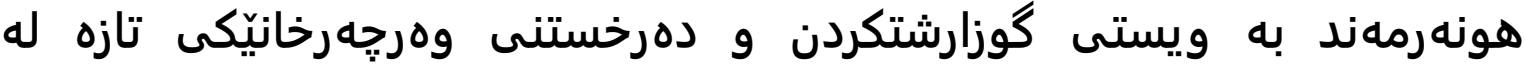
شيَوهيه كى نويَدا يِيِشان بدات

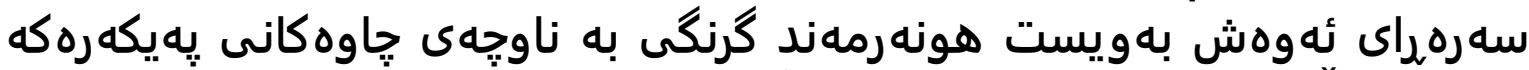

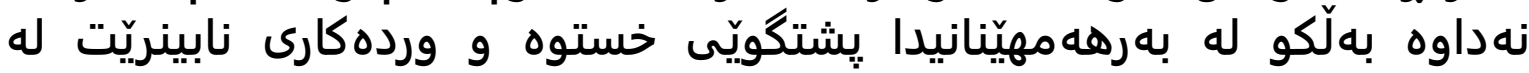

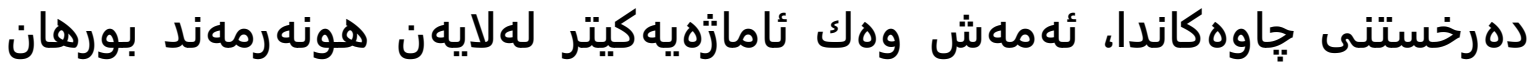

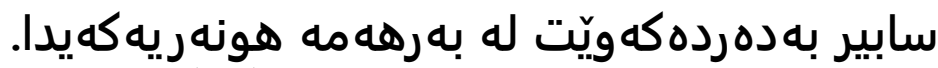

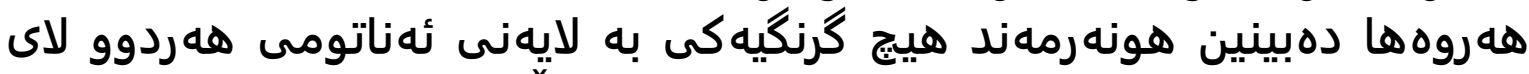

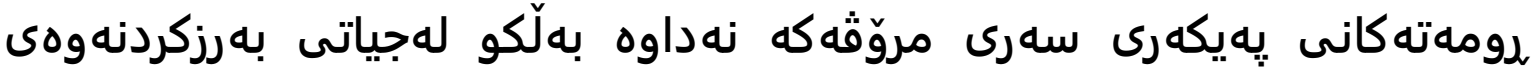

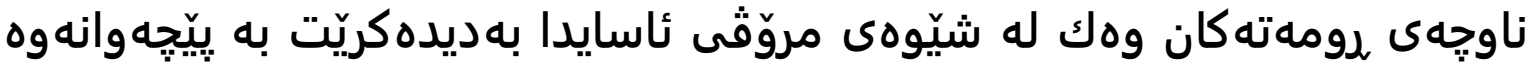

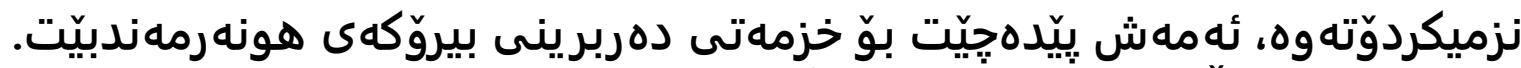

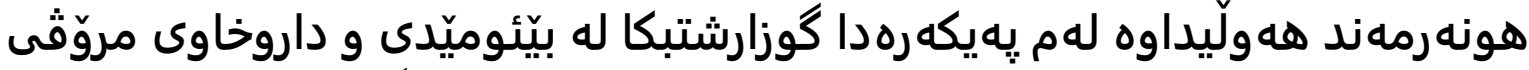

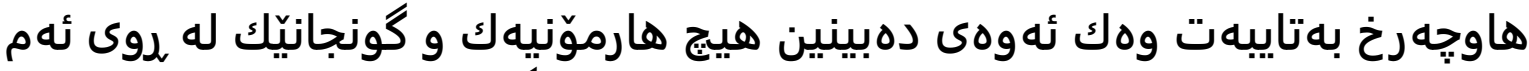

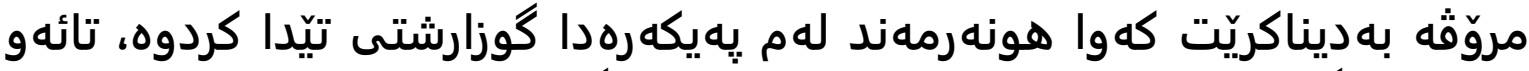

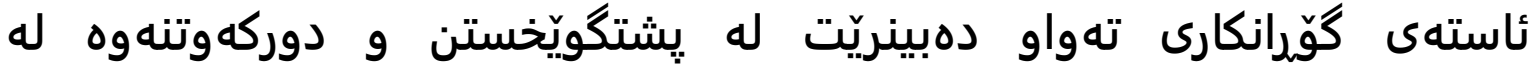

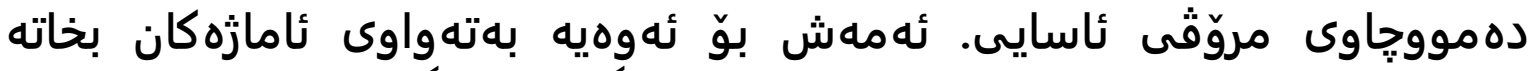

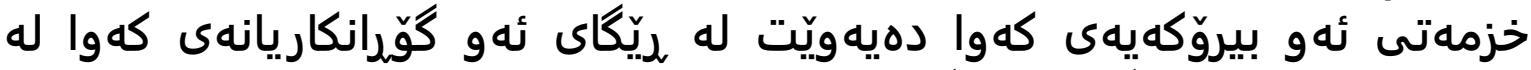

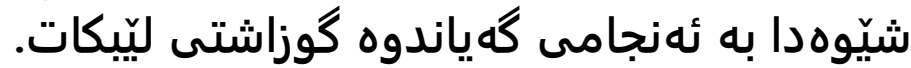

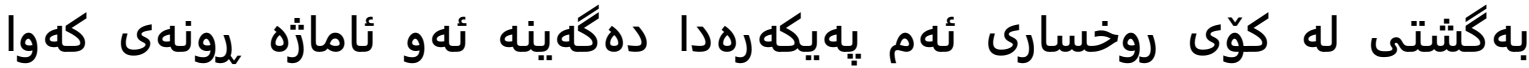

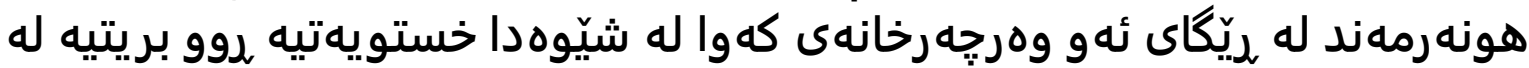

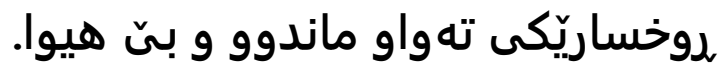

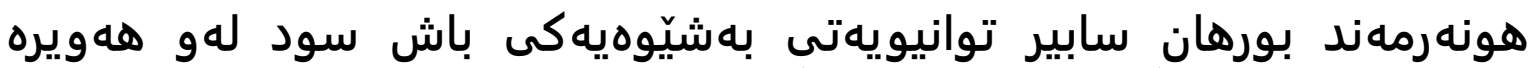

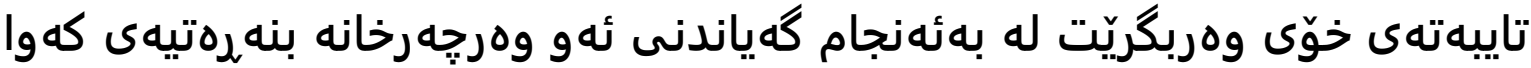

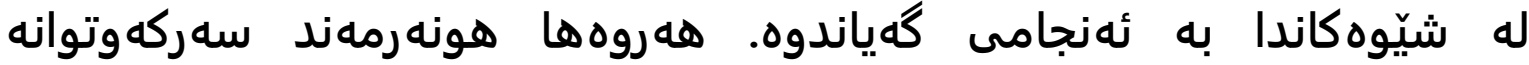




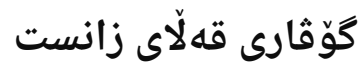

كوّقاريّكى زانستى وهرزيى باوهريِيكراوه له لايهن زانكوّى لوبنانى فهرهنسى دهردهجيّت - ههوليّر- كوردستان- عيّراق

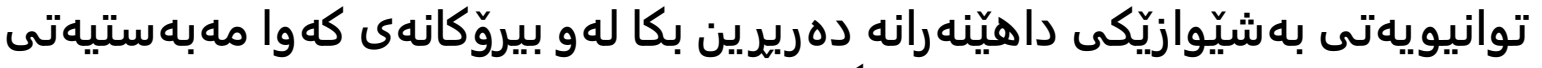

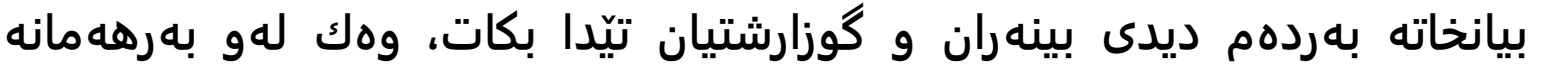

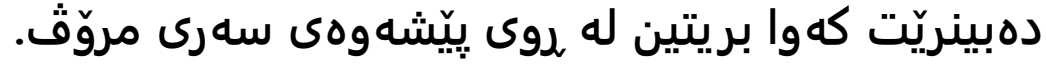

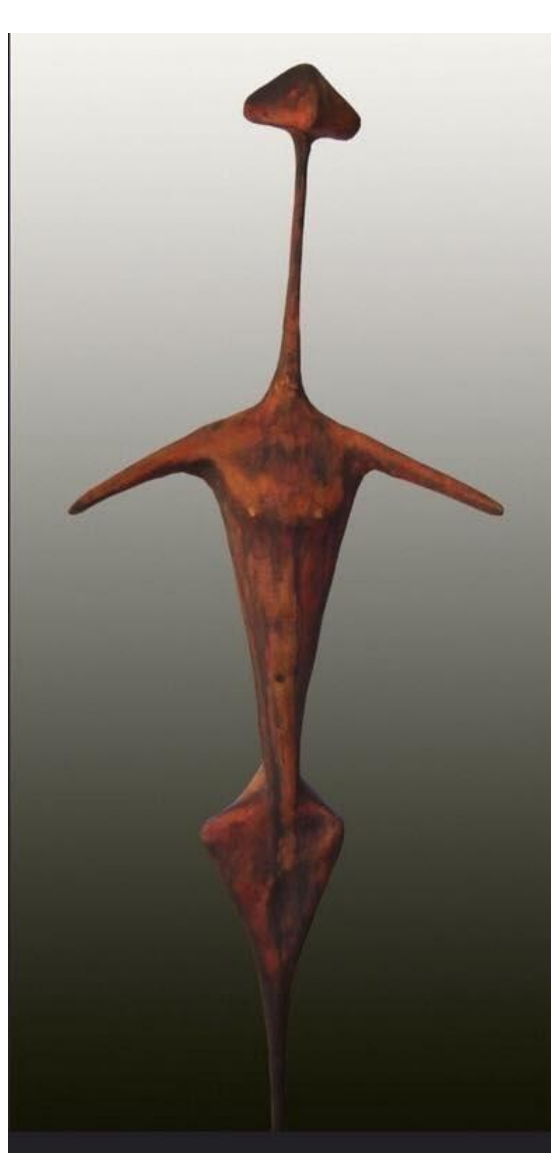

نمونهى دووهم

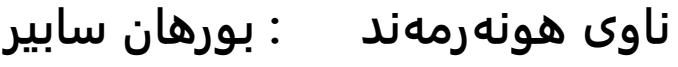
ناونيشانى يهيكهر : مروّق سالى به رهه مهيّنانى :

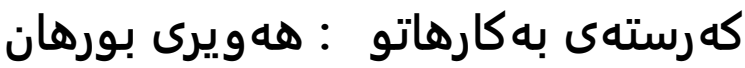
قهبارهى يهيكهر دوو مهتر 


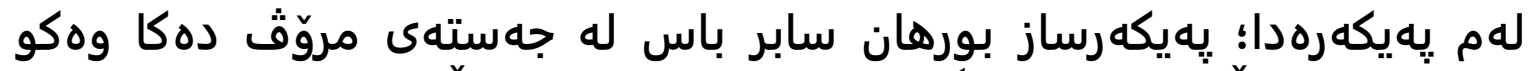

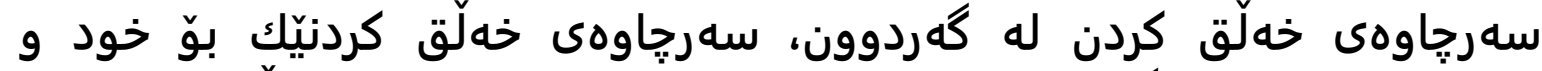

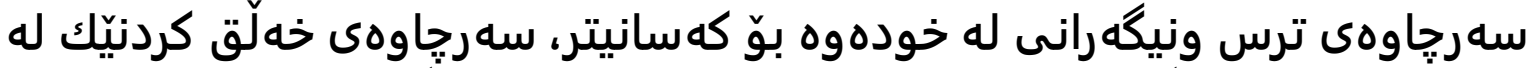

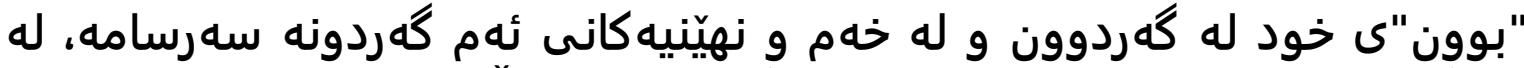

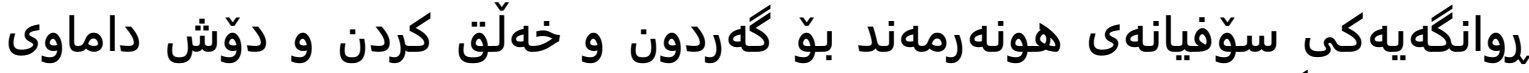

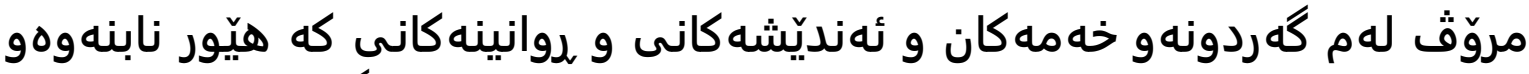

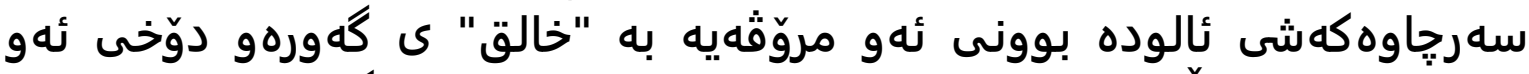

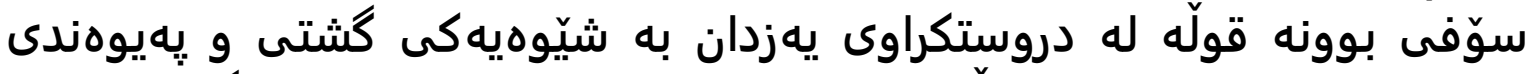

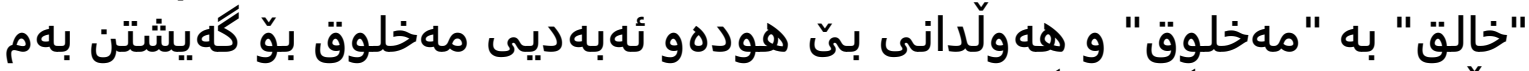

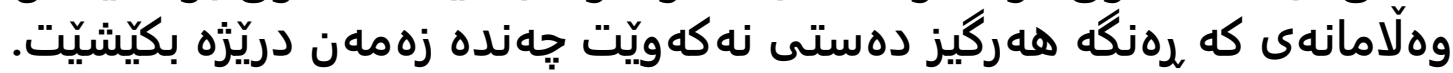

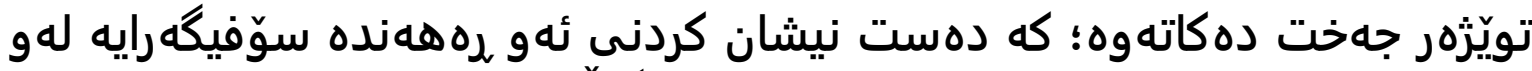

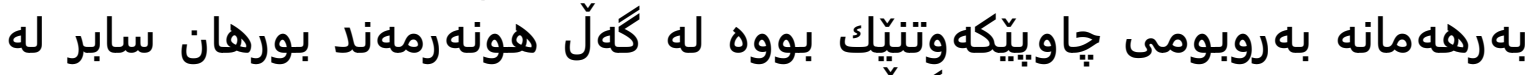

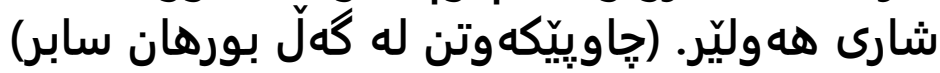

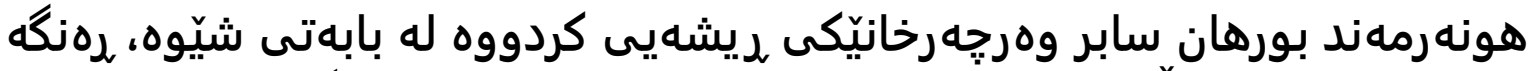

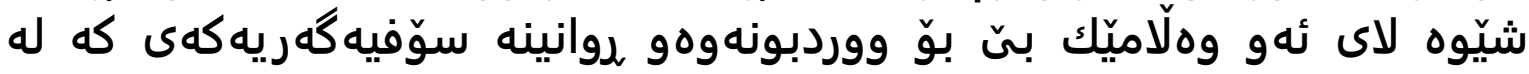

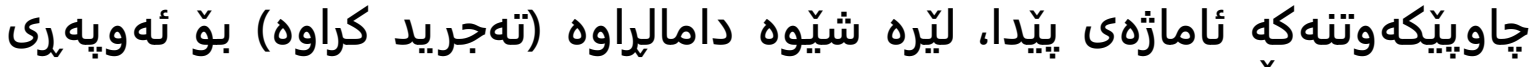

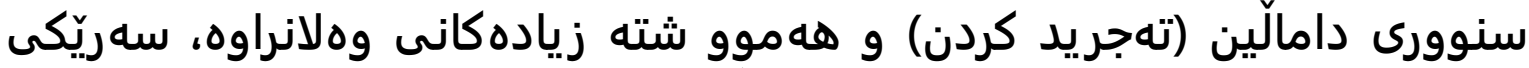

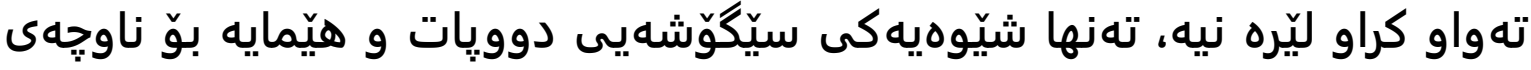

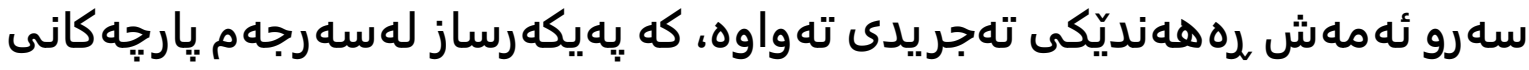

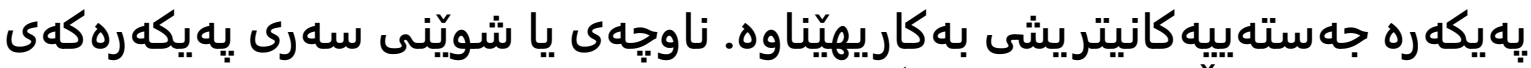

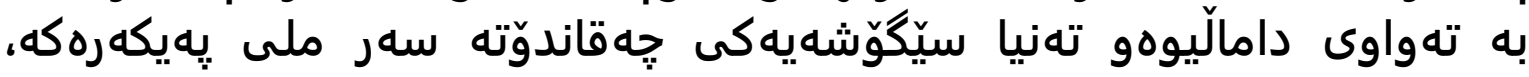

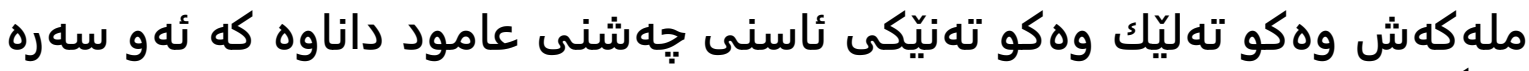

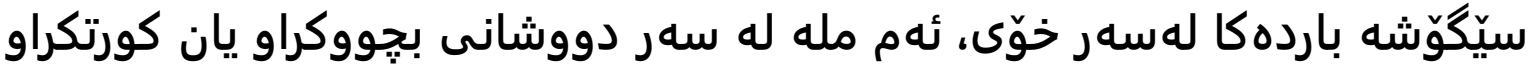

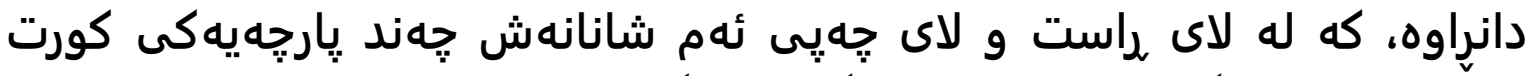

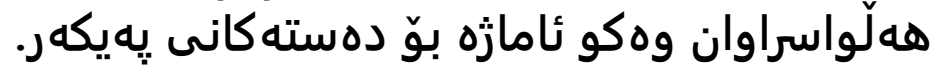

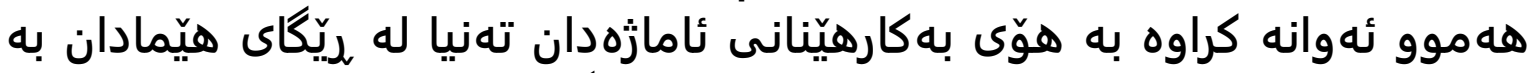

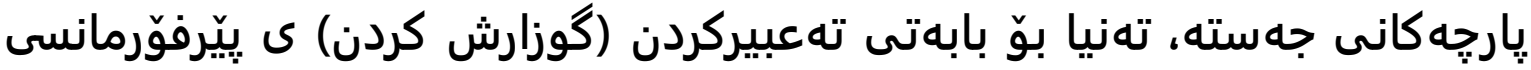

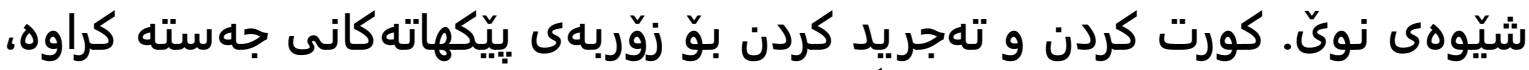

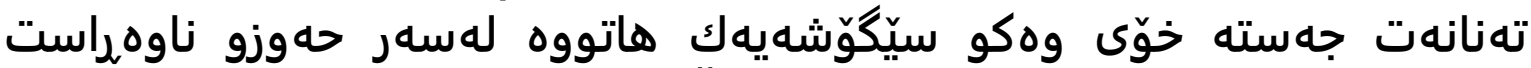

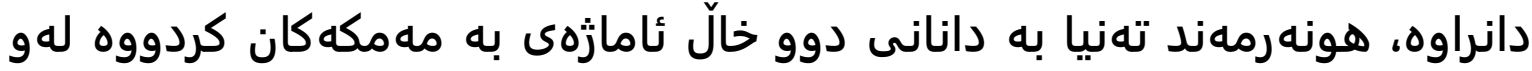

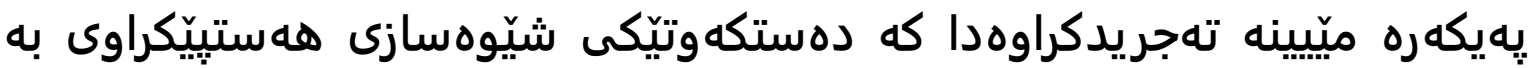




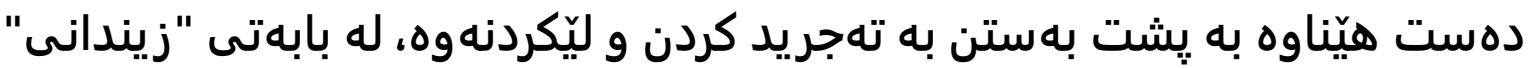

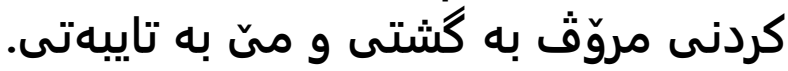

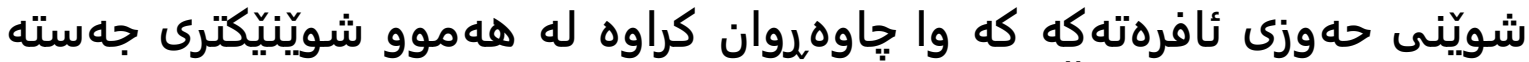

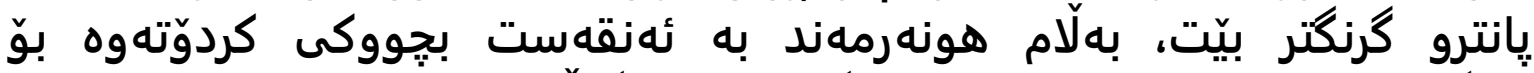

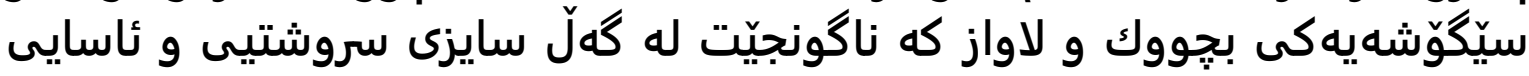
حهوز لاى ئافرهت.

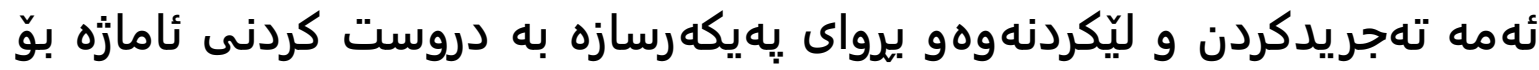

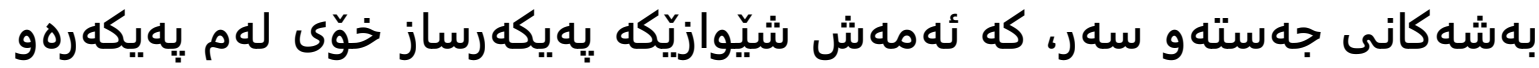

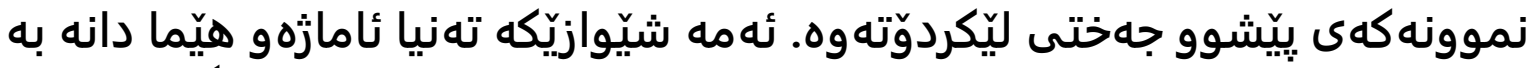

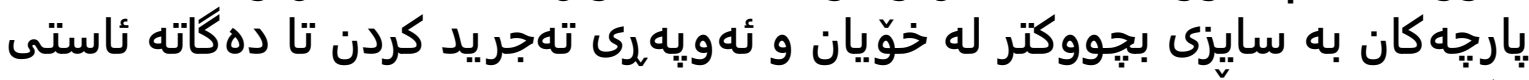

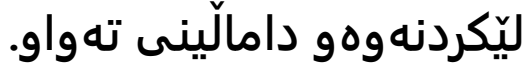

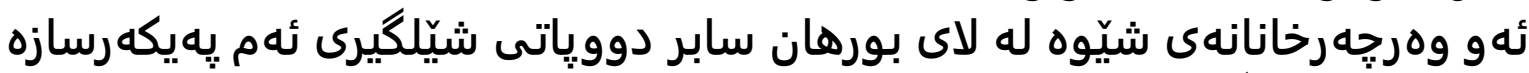

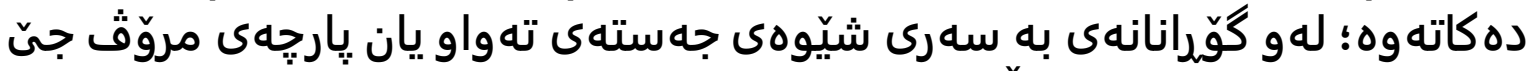

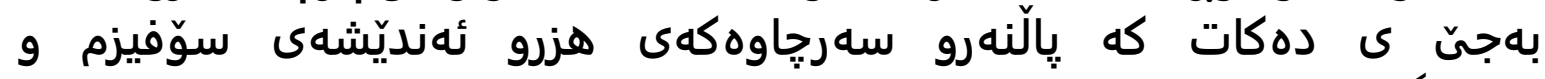

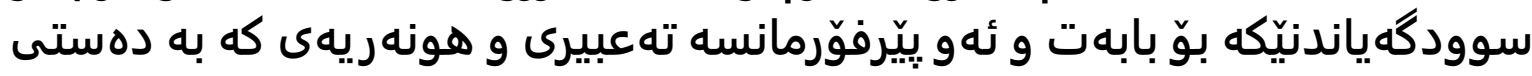
هيَنا.

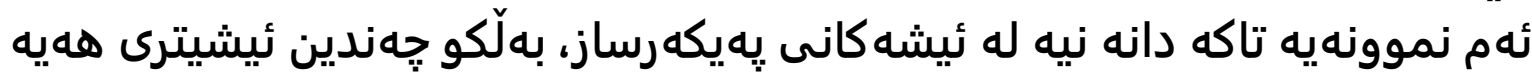

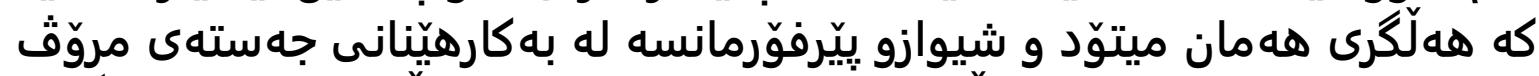

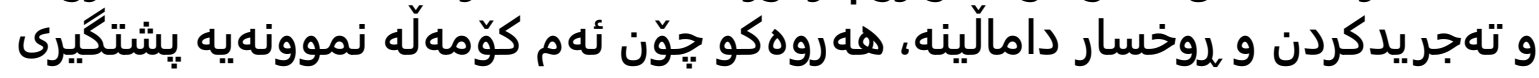
ئهم جوّره دهكهن.

نمونهى سيّههم 


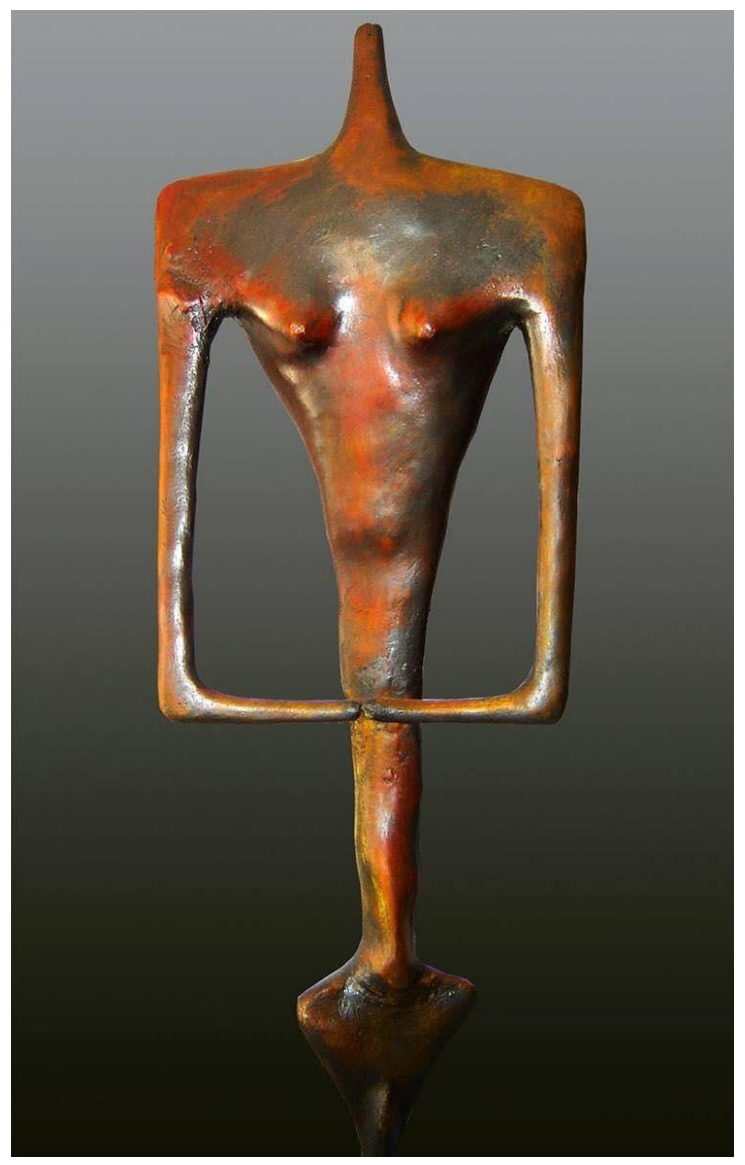

ناوى هونه رمهند بورهان سابير

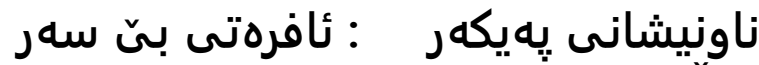

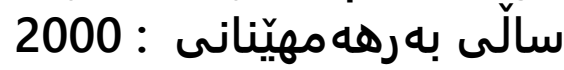

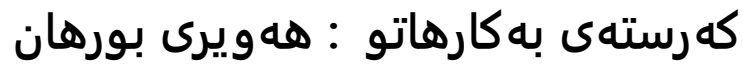

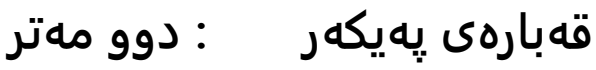

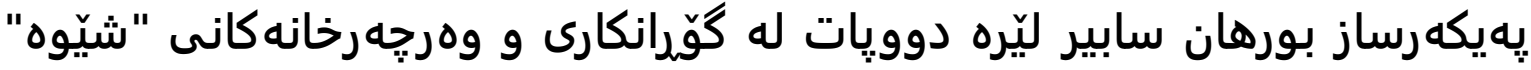

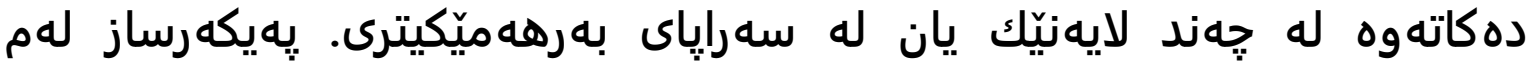

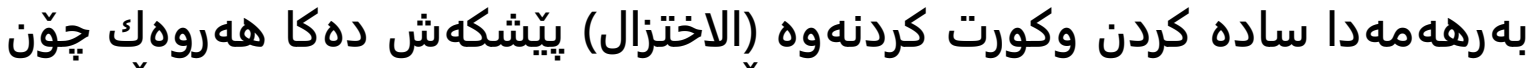

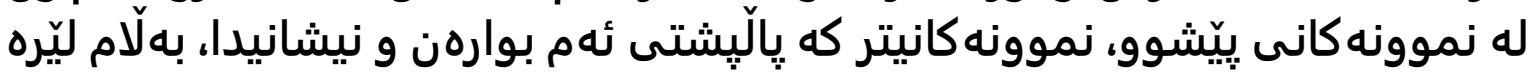

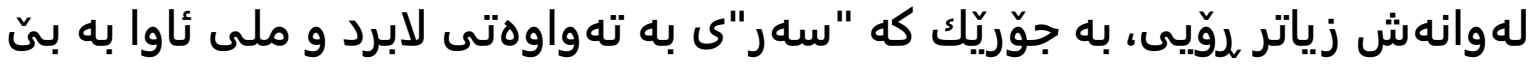

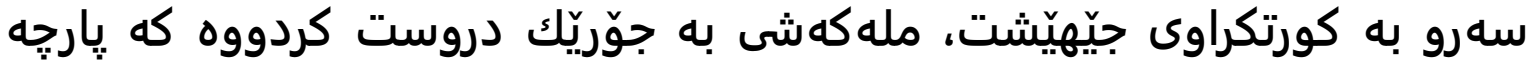

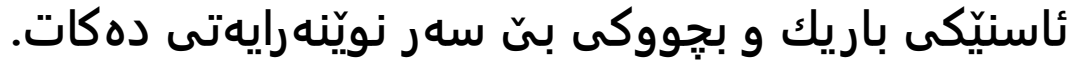

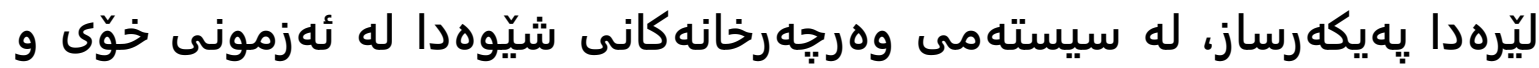

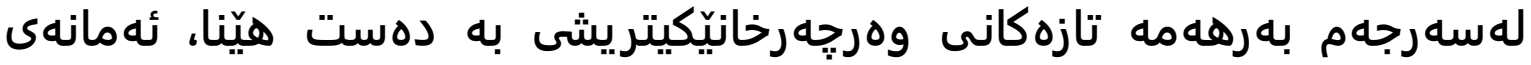

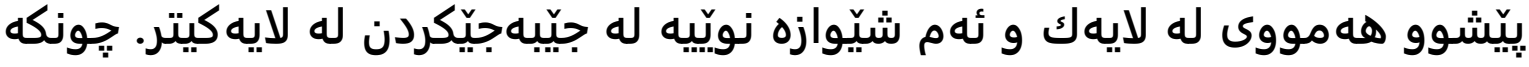


لهم شيِوازه تازهدا؛ شيّوه بيِجكه له لابردنى سهرو كورت كردنه

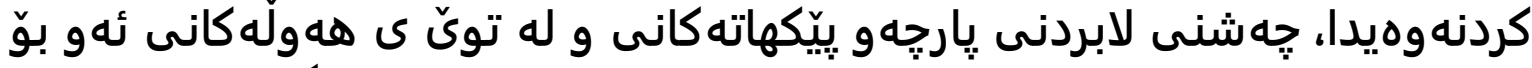

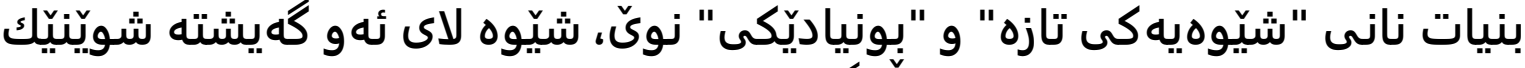

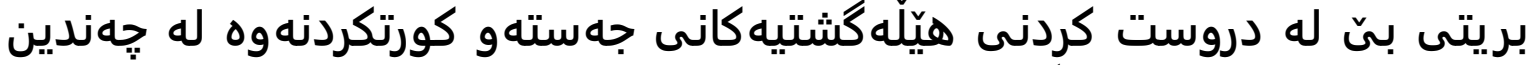

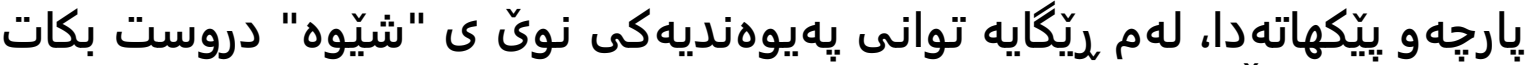

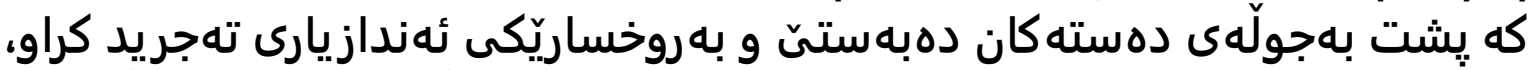

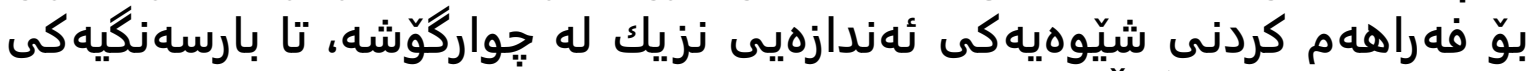

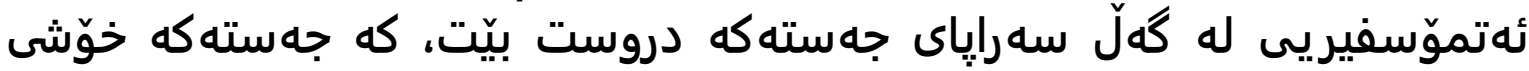

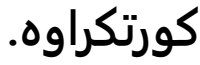

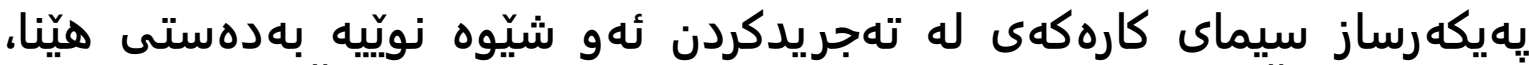

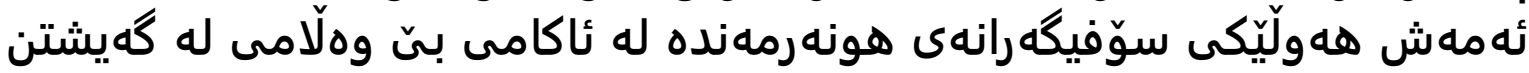
به يِيويستيه كانى روانينى سوّفييانه، ئهمانه ئهو

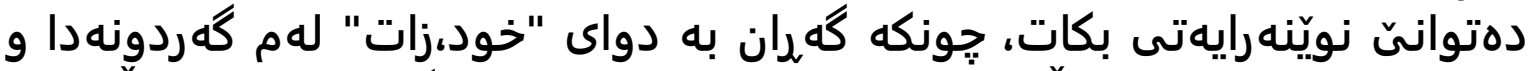

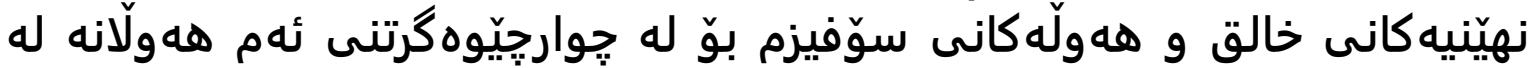

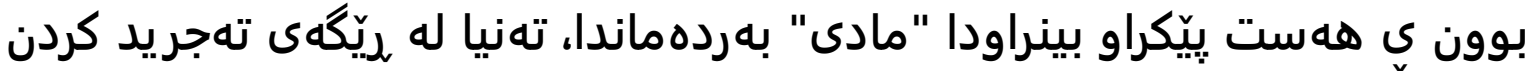

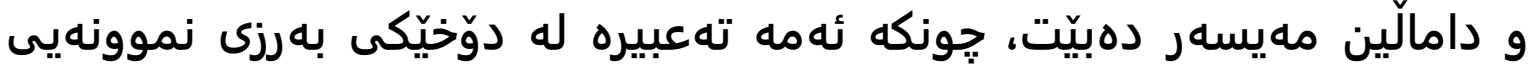

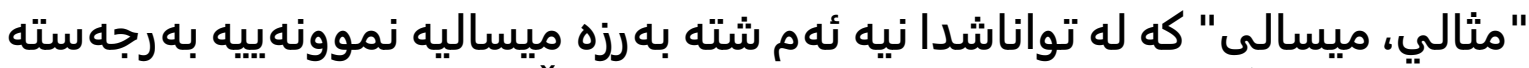

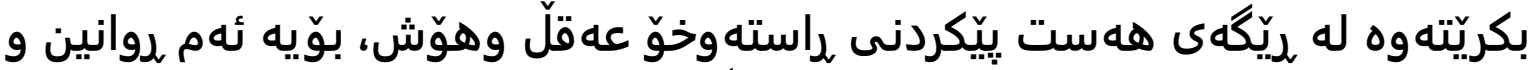

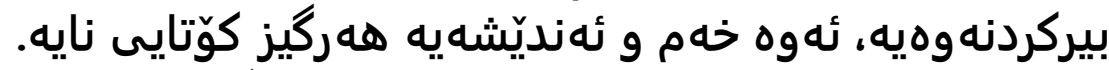

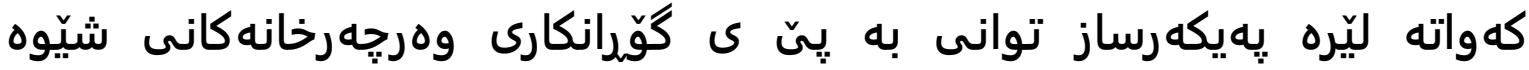

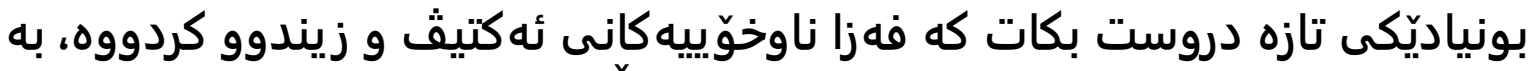

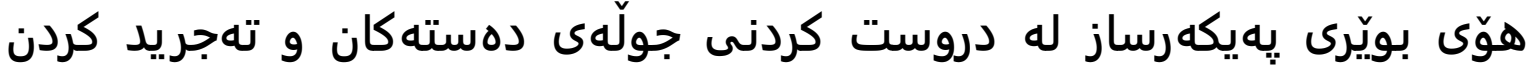

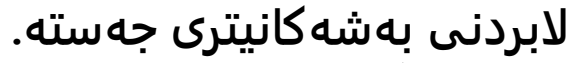

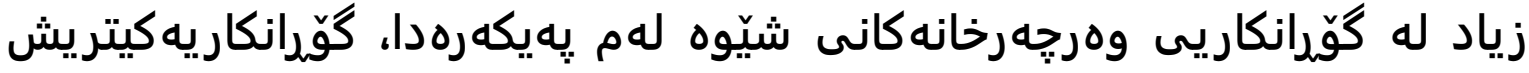

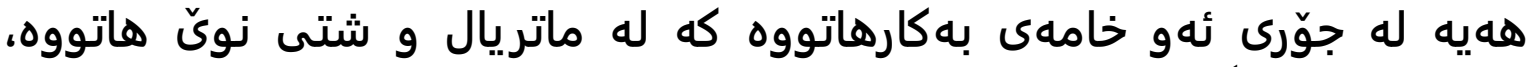

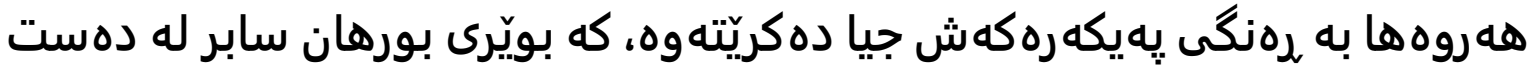

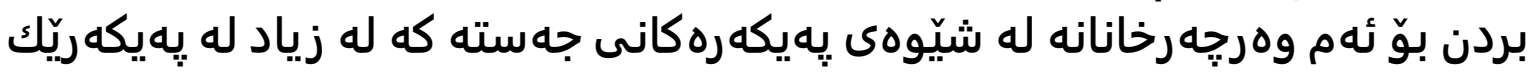

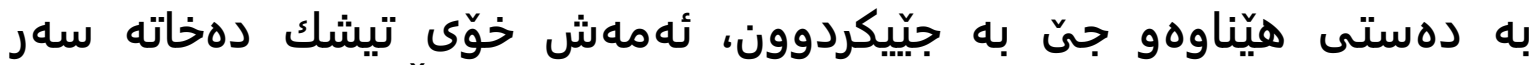

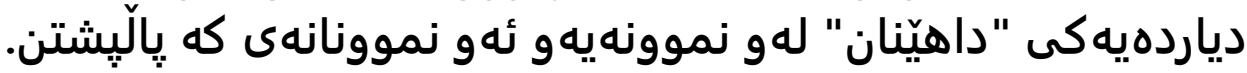

به شَ جِوارهم : ئهنجامى تويَزْينهوه 


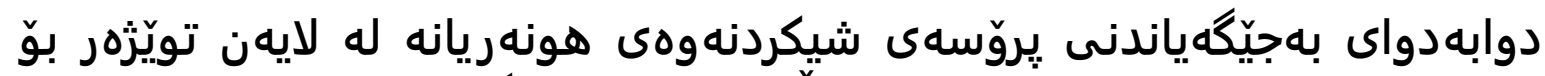

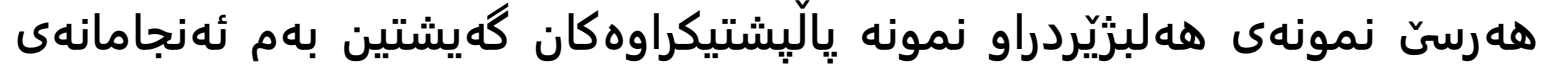
1. له ئهنجامى سادهكردنهوه و دابرينى شيّوهكان له شيّوه راسته

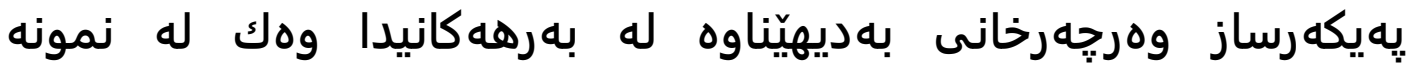
شيكراوه كاندا دياره.

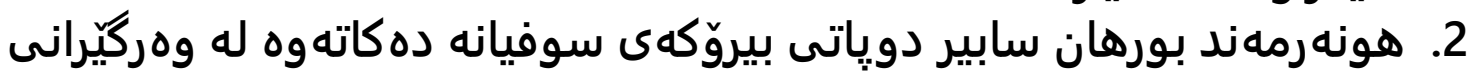

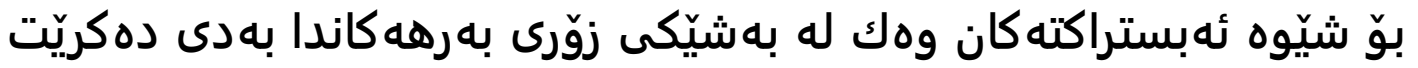

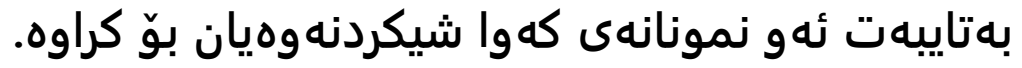

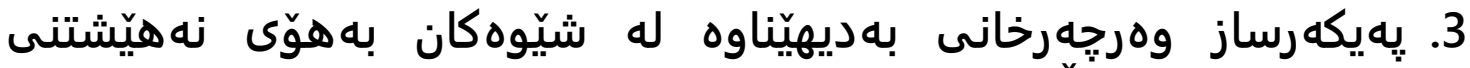

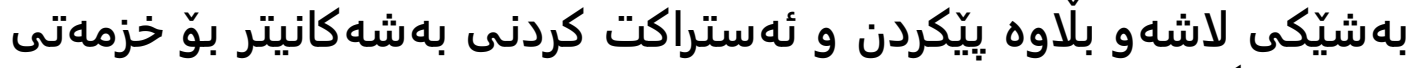

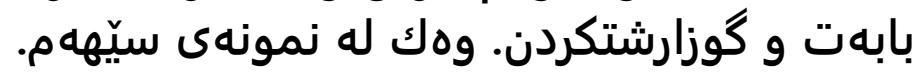

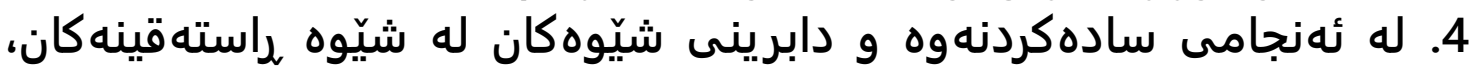

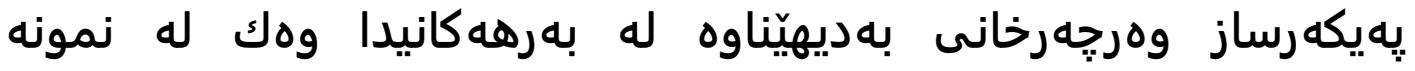
شيكراوه كان.

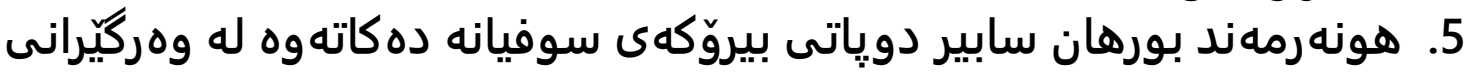

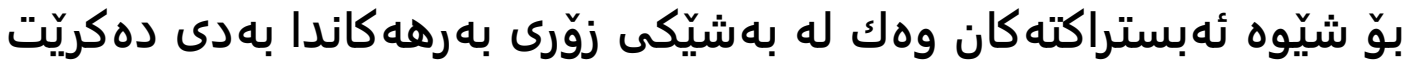

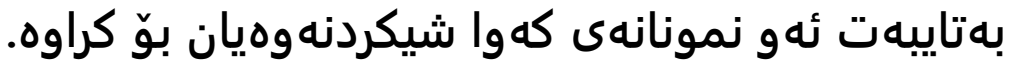

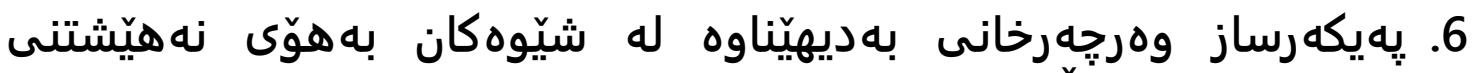

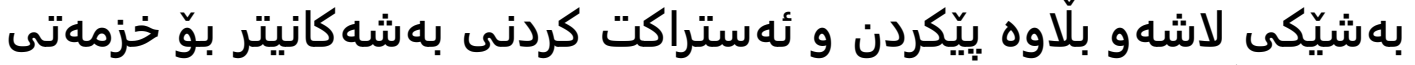

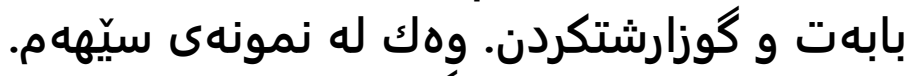

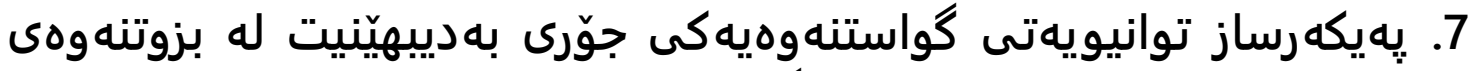

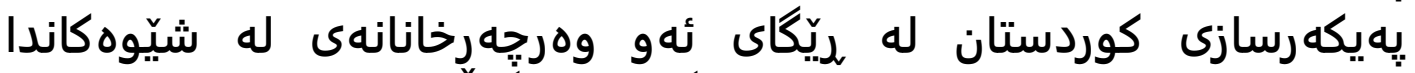

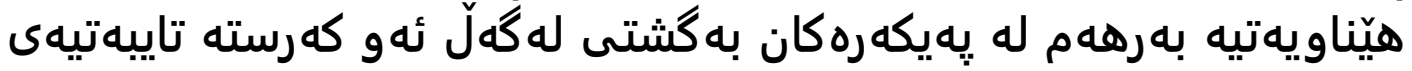

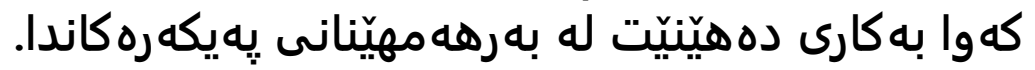

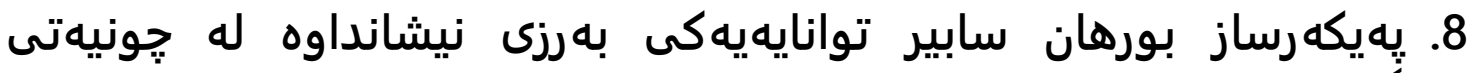

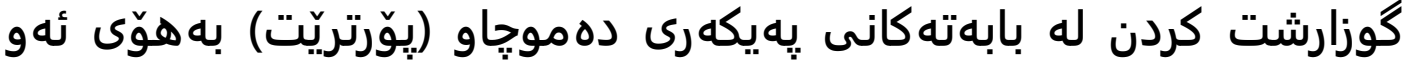

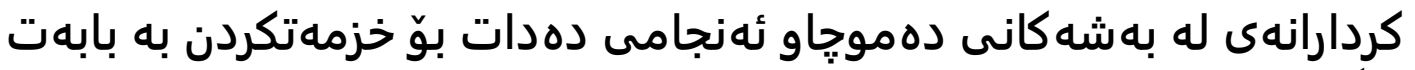

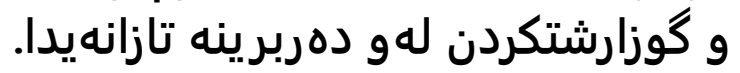

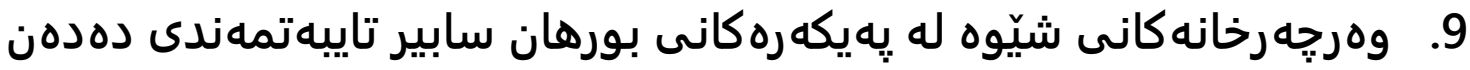

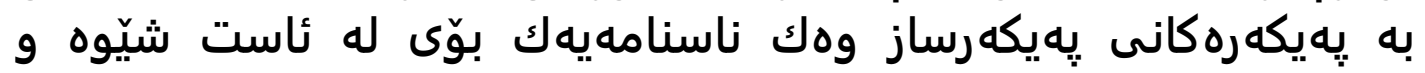


كوزارشتكردن و جيّبهجيّكردن به هوّى ئهو كهرسته تايبهتهى كهوا تايبهته به يه يكه رساز

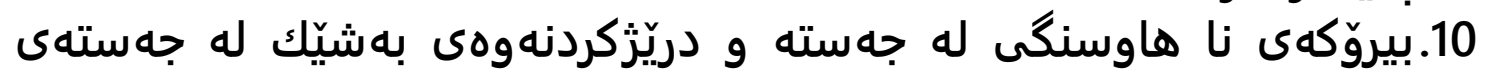

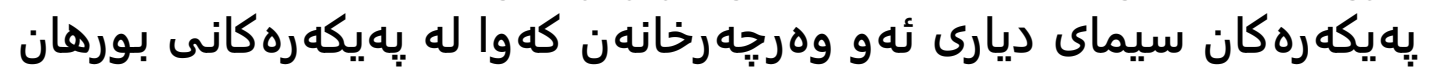
سابير دهبينريّن

$$
\text { سه رجاوهان }
$$

1. أبن منظور، جمال الدين محمد بن مكرم الانصاري, لسان العرب, ج3، دار

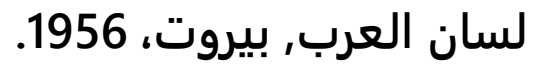

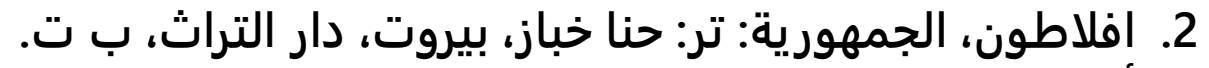

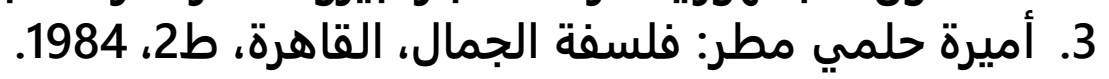
4. جيروم. ستولينتز. النقد الفني, ت. فؤاد زكريا, مطبعة الفة جامعة طين عين شمس, . 1974 5. ديوي ، جون . الفن خبرة ، ت : زكريا ابراهيم ، م : زكي نجيب محمود ، دار النهضة العربية : القاهرة ، 1963.

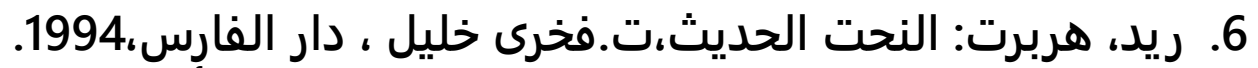

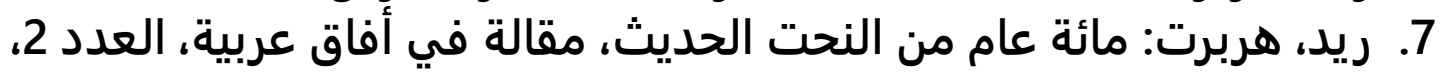
1989

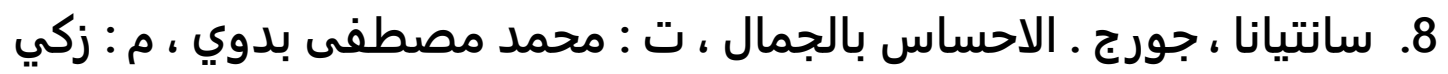

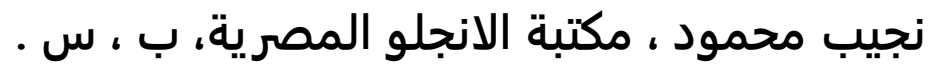

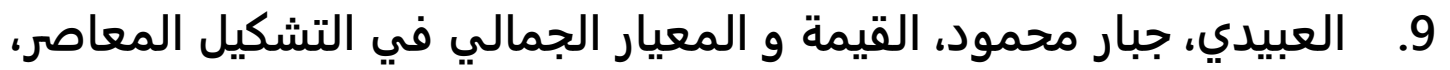

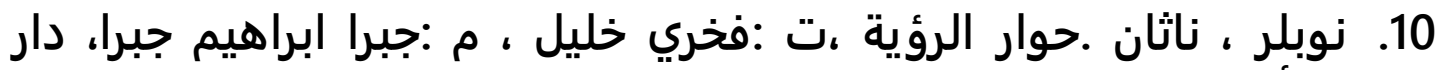

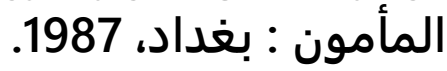
11. يوسف اخياط؛ قاموس المحيط، بيروت، دار لساد، لسان العرب، 1955.

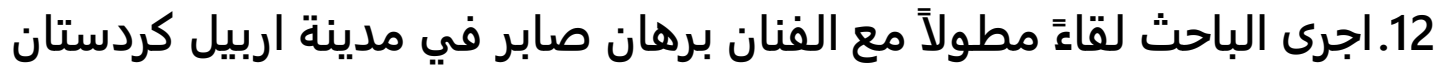

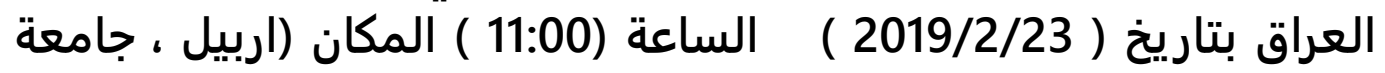

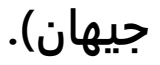

ملخص البحث يتناول البحث موضوع تحولات الثكل في اعمال النحات برهان صابر ، كما يسعى البحث ايضا الى الى

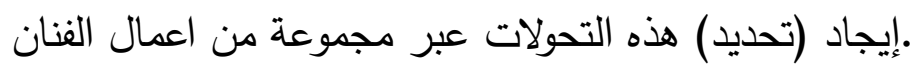


هذا البحث المعنون (تحولات الثكل في منحوتات الفنان برهان صابر) يتكون من أربعة فصول: الفصل الاول: يتألف من مشكلة البحث واهميته ونتائجه وحدوده وتحديد المصطلحات. الفصل الثاني: تتاول الإطار النظري المتكون من مبحثين: المبحث الاول: الثكل ومكانته في القيمة الفنية التشكيلية. المبحث الثاني يتكون من تحولات الثكل في الفن المعاصر .

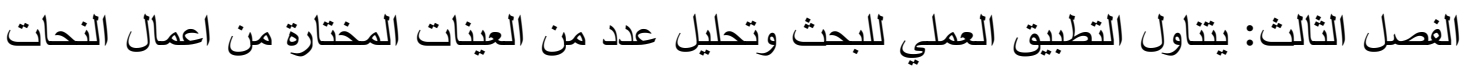
•برهان صابر لغاية تحديد مطالب هذا البحث الفصل الرابع: يتألف من نتائج البحث التي توصل اليها الباحث بعد تحليل عينات من اعمال النحات

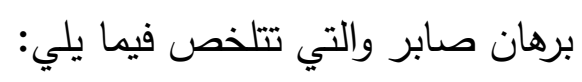

1. النحات يحقق تحولا في انتاجه كنتيجة للتبسيط وقطع الاشكال من أصلها الواقعي، كما يظهر في ئي

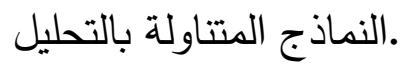

2. يستعيد الفنان برهان صابر الفكرة الصوفية وذلك بترجمتها الى اشكال تجريدية مثل القسم الأكبر من نتاجه وبالأخص النماذج المدروسة

3ـ يتوصل النحات الى التحولات في الثكل عن طريق اختزاله لقسم من الاجسام وتناثرها وتجريد الأقسام

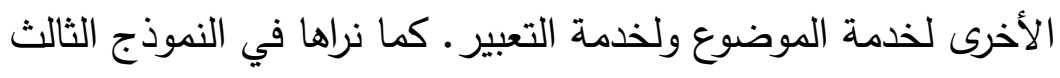

\section{Abstract}

This research concerns the transformations of the form in the work of Burhan Sabir, and also seeks to determine these transformations through s work.'some examples of the artist Transformations of form in the sculptures of the "This research entitled is divided into four sections: "artist Burhan Saber problematic of this search, The first part is about the definition of the its importance, its results, and its conceptual terminology. The second part is related to the theoretical framework, which is divided into two sections:

the first section discusses the form and its importance in the value of plastic art. 


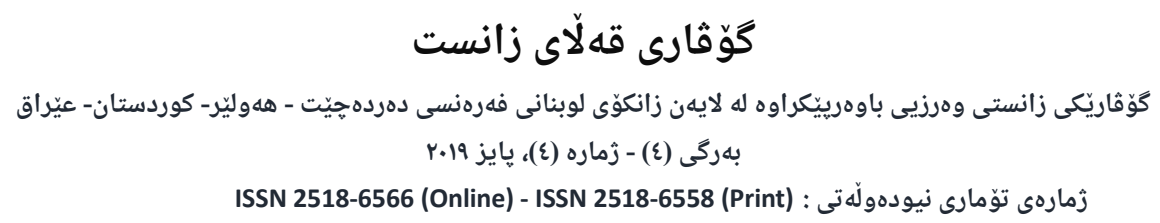

the second section concerns the transformations of form in contemporary art.

The third part is devoted to the practical application of the research and $s$ work 'it analysis a selected number of samples of the sculptor Burhan Sabir in order to determine the finalities of this research.

The fourth part consists in the results obtained by the researcher s work, which are 'through the analysis of samples of Burhan Sabir summarized in three parts:

1-The sculptor Burhan Sabir realizes the change in his work, as a result of a simplification and rupture of the form of their realist origin, as shown in the samples analyzed.

2-The artist Burhan Sabir uses again the Sufi idea, through translating it into abstract forms as the major part of his creation.

3-The artist manages to transform the form by purifying some parts of the body and by abstracting other parts, in order to serve the subject and the expression, as we can see in the third sample. 